\title{
Temporal and spatial scaling of planktonic responses to nutrient inputs into a subtropical embayment
}

\author{
Evelyn F. Cox $^{1, *}$, Marta Ribes ${ }^{1,2}$, Robert A. Kinzie III ${ }^{1}$ \\ ${ }^{1}$ Hawai'i Institute of Marine Biology, University of Hawai'i, PO Box 1346, Kāne'ohe, Hawai'i 96744, USA \\ ${ }^{2}$ Present address: Institut de Ciències del Mar (CMIMA-CSIC), Passeig Marítim 37-49, 08003 Barcelona, Spain
}

\begin{abstract}
We carried out a study of the spatial and temporal effects of land-derived material on water column nutrients and plankton dynamics in a subtropical estuary. The study had 2 parts: (1) a 3 yr synoptic monitoring program, and (2) a shorter 1.5 yr study during the second half of the program, which focused on individual pulses driven by discrete rainfall events. Although we found spatial differences in some water column parameters within Kāne'ohe Bay and an adjacent oceanic site, inorganic nutrient levels were generally comparable in the Bay and offshore. One difference was that Prochlorococcus spp. numerically dominated the plankton at the oceanic site whereas Synechococcus spp. dominated at all Bay sites. The switch in dominance appears to be due to light characteristics and dissolved organic nitrogen (DON), but not dissolved inorganic nutrient availability. There were no annual cycles in water column parameters within the Bay; however, a comparison of dry and wet seasons did show some differences. Planktonic cell abundance was in general lower during the wet season, with the exception of opportunistic diatoms that were more abundant during the wet season. A drought during the study period may have influenced our results. Pulses were characterized by an elevation in inorganic nutrient concentrations in the Bay close to the stream mouth. The general response was an increase in abundance of microphytoplankton and chl $a$ after a 3 to $6 \mathrm{~d}$ lag following the nutrient increase. Picophytoplankton showed an increase in fluorescence per cell after a 12 to $24 \mathrm{~h}$ lag, probably related to a decrease in irradiance associated with turbidity in runoff. The Bay can act as source of dissolved inorganic nutrients and plankton for oceanic waters; however, planktonic populations in the Bay are primarily autochthonous and do not represent an oceanic source of nutrients for plankton consumers within Kāne'ohe Bay.
\end{abstract}

KEY WORDS: Picoplankton $\cdot$ Phytoplankton $\cdot$ Zooplankton $\cdot$ Nutrients $\cdot$ Runoff

\section{INTRODUCTION}

Coral reef ecosystems are characterized by low net community productivity (similar to the surrounding oligotrophic oceanic water) such that the system accumulates biomass slowly and exports little (Hatcher 1990). Typically, tropical oceanic water has low nutrient concentrations (Crossland \& Barnes 1983, Furnas 1992) and is dominated, in terms of biomass and production, by pico- $(0.2$ to $2 \mu \mathrm{m})$ and nanoplankton (2 to $20 \mu \mathrm{m}$ ) (Ducklow 1990, Olson et al. 1990 a,b, Tremblay \& Legendre 1994, but see Scharek et al. 1999). Advec- tion from the surrounding ocean (including upwelling) and terrestrial run-off are considered to be the main sources of new nutrients supporting net production in reef ecosystems (Furnas et al. 2005).

The oligotrophic conditions of oceanic waters surrounding coral reefs can be quite different from relatively nutrient-rich inshore conditions on high islands or atolls. For example, high productivity has been described within French Polynesian atoll lagoons in comparison to oceanic waters (Charpy 1996, Ferrier-Pagès \& Furla 2001), and these lagoons can also represent a source of nitrogen for the adjacent oceanic waters 
(Charpy-Roubaud et al. 1990). Short episodes of high stream discharge can be responsible for most of the annual delivery of dissolved and particulate materials into bays or lagoons on high islands (Taguchi \& Laws 1989, Dubinsky \& Stambler 1996, Hoover 2002, Ringuet \& MacKenzie 2005), increasing dissolved nutrient concentrations (N, P and dissolved organic $\mathrm{C}$ [DOC]) in the receiving water. However, the scale of spatial and temporal responses of plankton communities to stream discharge and subsequent nutrient inputs are still poorly understood, especially within atolls or bays with high water exchange with adjacent oceanic water.

Kāne'ohe Bay is located on the windward northeast coast of O'ahu, Hawai'i, and is one of the most intensively studied coral reef systems in the world (e.g. Smith et al. 1981, Taguchi \& Laws 1987, 1989, Hunter \& Evans 1995, Laws \& Allen 1996, see also www. hawaii.edu/cisnet). Water circulation in the Bay is primarily influenced by tradewinds that drive oceanic water across the forereef and out through a northern deep channel (Fig. 1). At our north bay (NB) study site, most of this water flows quickly offshore (Bathen

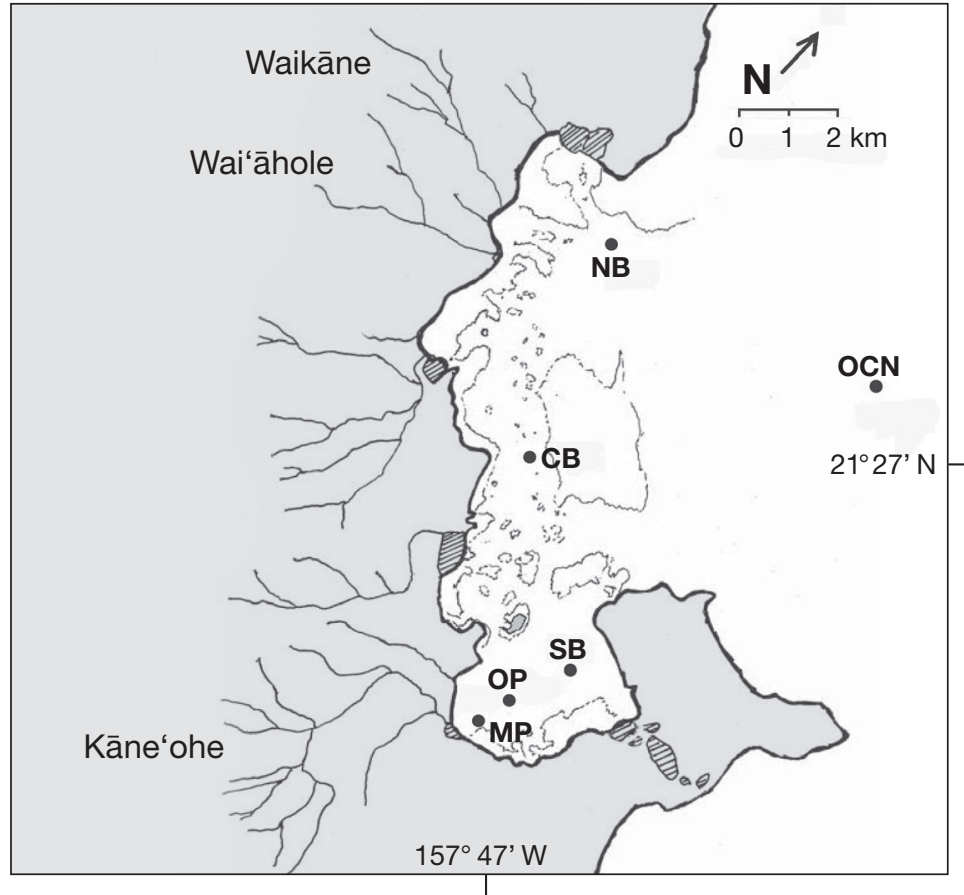

Fig. 1. Kāne`ohe Bay, O'ahu, Hawai'i. Major stream systems, fish ponds (hatched), and reefs (dotted) shown. (•) Sampling site (OCN: oceanic site; NB: north bay; CB: central bay; SB: south bay; OP: outside plume; MP: mid plume)
1968). At the more protected central bay (CB)

and, especially, south bay (SB and MP) study sites, water remains in the system for longer periods of time (Bathen 1968, Smith et al. 1981). Stream discharge in Hawai'i responds rapidly to brief, intense rainstorms that occur at unpredictable intervals throughout the year (Kinzie et al. 2006). As stream channels are short and steep and rain events can be locally intense, pulsed discharge into Kāne'ohe Bay can result in marked responses by the Bay system (Banner 1974, Taguchi \& Laws 1989, Jokiel et al. 1993, Hoover 2002, Ringuet \& Mackenzie 2005). Pulsed discharge can exceed median streamflow by 2 to 3 orders of magnitude (Oki 2004). In addition, channelization may increase the peak discharge and decrease the duration of pulses (Laws \& Roth 2004).

The aim of this study was to reveal the pattern of distribution of planktonic communities over a range of stream discharge conditions in Kāne'ohe Bay and over a spatial gradient of exchange with oceanic water. We monitored the temporal dynamics of annual cycles as well as short-term stream discharge pulses. As reported in previous studies (Chisholm 1992, Agawin et al. 2000), we expected that increased nutrients would shift phytoplankton to larger size classes, followed by a similar change in zooplankton size. During periods of low nutrient input, such as during a drought, phytoplankton should be dominated by picoplankton (Raven
1998). Our main goal was to reveal the type and temporal and spatial scales of responses of planktonic components to nutrient increase associated with stream discharge, and the effects of oceanic water and Bay circulation patterns on the dissipation of planktonic changes.

\section{MATERIALS AND METHODS}

Baseline sampling. From 1998 to 2001, a monitoring program (CISNet Kāne'ohe Bay: www.hawaii.edu/cisnet) collected data for comparison with earlier work during the 'sewage' and 'post-sewage' periods in Kāne'ohe Bay (Smith et al. 1981). Parameters monitored in this program included water column chl $a$ and nutrients, as well as physical factors including temperature, salinity, light attenuation and suspended sediments. Sampling was conducted at 5 stations (Fig. 1) and took place every $2 \mathrm{wk}$ for north bay (NB), central bay (CB), south bay (SB) and mid plume (MP) sites and roughly every 3 mo for oceanic (OCN) sites. Depth (lead sounding) and Secchi depth $(30 \mathrm{~cm}$ diameter white disk) were recorded at each site. Profiles for temperature and salinity were obtained with a SeaBird CTD. Light penetration was determined using paired deck and submerged readings with photosynthetically 
active radiation (PAR) meters (LiCor) equipped with upward-facing cosine sensors. Water was collected using a submersible pump, mounted on a float to maintain the intake at a constant depth of $0.5 \mathrm{~m}$. All water column parameters were taken from this $0.5 \mathrm{~m}$ depth unless otherwise noted. Water samples were all held in 41 opaque acid washed plastic bottles, after initial rinsing with water from the pump, and kept on ice until processed. Four water samples were collected at each site.

In the last $1.5 \mathrm{yr}$ of this program, we initiated a sampling project addressing the planktonic communities in greater detail. For this more intense program, pico-, nano- and microplankton (collectively called the microbial fraction) were collected from the water column samples described above. At 3 of the stations (NB, CB, and SB), zooplankton samples were also taken every 2nd wk.

In addition, during this period we intensively monitored plumes arising from rainfall episodes. These plumes developed at the mouth of Kāne'ohe Stream (Fig. 1) and could be visually followed for hours to days (Jokiel et al. 1993).

Nutrient analysis. Aliquots of approximately $100 \mathrm{ml}$ were taken from the $0.5 \mathrm{~m}$ water samples and filtered though a $25 \mathrm{~mm} \mathrm{GF} / \mathrm{F}$ filter in a syringe holder. Samples were collected in acid-rinsed $125 \mathrm{ml}$ plastic bottles, first rinsed with filtered sample water. Samples were frozen and analyzed for inorganic and total nutrients using the methods of Smith et al. (1981) by SOEST Analytical Laboratory (until April 2001) and University of Washington Marine Chemistry Laboratory (from April to July 2001). Parameters measured were: $\mathrm{NH}_{4}{ }^{+}$(referred to as ammonium in this paper), $\mathrm{NO}_{3}{ }^{-},\left(+\mathrm{NO}_{2}{ }^{-}\right.$) (as nitrate), $\mathrm{PO}_{4}^{-3}$ (as phosphate), $\mathrm{SiO}_{2}$ (as silicate), total dissolved nitrogen (TDN), and total dissolved phosphorus (TDP).

Particulate carbon and nitrogen. Total particulate water column carbon and nitrogen were measured by filtering 11 of water on pairs of pre-combusted GF/F glass fiber filters, with 3 replicates from different water sample bottles. Acidification $(10 \% \mathrm{HCl})$ was performed on 1 filter of each pair to dissolve carbonates. Filters were dried overnight at $60^{\circ} \mathrm{C}$ and stored in desiccators until analyzed with a Perkin-Elmer CHN Analyzer.

Chlorophyll analysis. Three size fractions were collected for the CISNet program $(<2 \mu \mathrm{m},>2 \mu \mathrm{m}$, and $\mathrm{GF} / \mathrm{F})$. Water samples were prefiltered through a $183 \mu \mathrm{m}$ mesh to remove large particles. Next, approximately $250 \mathrm{ml}$ was filtered onto a $47 \mathrm{~mm}$ Whatman GF/F filter and another $250 \mathrm{ml}$ filtered onto a $47 \mathrm{~mm}$ $2.0 \mu \mathrm{m}$ membrane filter (Millipore Isopore). Approximately $100 \mathrm{ml}$ of the filtrate that passed through the $2.0 \mu \mathrm{m}$ membrane filter was then filtered onto a $47 \mathrm{~mm}$
$0.2 \mu \mathrm{m}$ membrane filter (Millipore Isopore). Volumes filtered were recorded for each sample. All 3 size fractions were obtained in triplicate for each site. Filters were placed into $15 \mathrm{ml}$ plastic centrifuge tubes, and $10 \mathrm{ml}$ of $100 \%$ acetone was added to each sample tube. Each sample was sonicated on ice in the centrifuge tubes for $20 \mathrm{~s}$ with a HeatSystems W-370 sonicator set at maximum power for the micro tip. Samples were held at $-5^{\circ} \mathrm{C}$ in the dark until reading, usually within $24 \mathrm{~h}$.

Before reading, samples were cleared in a refrigerated centrifuge at $20000 \mathrm{rpm}$ for $20 \mathrm{~min}$ and then allowed to come to room temperature. Chlorophyll was determined from fluorescence measured on a Turner Designs 10-AU fluorometer. Fluorescence before and after acidification was used to determine chl a using the equations given in Trees et al. (2000). The Turner Designs solid chlorophyll standard was run at the beginning and end of each set of samples. Additionally, a dilution series of pure chl a (Sigma) was measured at the end of each sample run.

Pico- and nanoplankton. We used flow cytometry to quantify heterotrophic bacteria, Prochlorococcus spp. (hereafter Prochlorococcus), Synechococcus spp. (hereafter Synechococcus), and picoeukaryotes. Three water samples ( $2 \mathrm{ml}$ from $4 \mathrm{l}$ water sample bottles) were fixed with $1 \%$ paraformaldehyde $+0.05 \%$ glutaraldehyde (final concentration) and frozen in liquid nitrogen. Samples were stored at $-80^{\circ} \mathrm{C}$ or in dry ice until processing. For determination of bacterial and picoeukaryote abundance we used a B\&D FACScalibur bench machine as described in Gasol \& Morán (1999). Nanoeukaryote abundance was determined on $20 \mathrm{ml}$ subsamples stained with DAPI and filtered through a $0.2 \mu \mathrm{m}$ filter (Nucleopore). Stained cells were directly enumerated using epifluorescence microscopy. Cell sizes of heterotrophic bacteria, Synechococcus, picoeukaryotes, and nanoeukaryotes were measured on the same filters using framegrabber and software for image analysis as described in Massana et al. (1997). Fluorescence (red indicating chlorophyll and orange indicating phycoerythrin) per cell and relative to beads was calculated from flowcytometry data as reported in Gasol \& del Giorgio (2000).

Microplankton (phytoplankton and ciliates). To quantify phytoplankton and ciliate cell numbers, $350 \mathrm{ml}$ water samples (from 41 water sample bottles) were preserved with Lugol's solution (10\% final concentration). Subsamples of $100 \mathrm{ml}$ were transferred to settling chambers, and major groups of microphytoplankton were quantified using an inverted microscope.

Cell sizes (length and width) were measured using an ocular micrometer. Cell biovolumes were estimated from the length and width measurements, assuming 
Table 1. C and N conversion factors for selected cell types

\begin{tabular}{|llll|}
\hline Cell type & Carbon & Nitrogen & Reference \\
\hline $\begin{array}{l}\text { Heterotrophic } \\
\text { bacteria }\end{array}$ & $9.3 \mathrm{fg} \mathrm{cell}^{-1}$ & $1.8 \mathrm{fg} \mathrm{cell}^{-1}$ & $\begin{array}{l}\text { Gundersen } \\
\text { et al. (2002) }\end{array}$ \\
$\begin{array}{l}\text { Prochlorococcus } \\
\text { spp. }\end{array}$ & $37 \mathrm{fg} \mathrm{cell}^{-1}$ & $4 \mathrm{fg} \mathrm{cell}^{-1}$ & $\begin{array}{l}\text { Heldal } \\
\text { et al. (2003) }\end{array}$ \\
$\begin{array}{l}\text { Synechococcus } \\
\text { spp. }\end{array}$ & $192 \mathrm{fg} \mathrm{cell}^{-1}$ & $21 \mathrm{fg} \mathrm{cell}^{-1}$ & $\begin{array}{l}\text { Heldal } \\
\text { et al. (2003) }\end{array}$ \\
$\begin{array}{l}\text { Picoeukaryotes \& } \\
\text { nanoeukaryotes }\end{array}$ & $183{\mathrm{fg} \mu \mathrm{m}^{-3}}^{\text {Diatoms \& }}$ & $26.1{\mathrm{fg} \mu \mathrm{m}^{-3}}^{\text {Caron }}$ & $\begin{array}{l}\text { et al. (1995) } \\
\text { dinoflagellates }\end{array}$ \\
\hline
\end{tabular}

consisted of smaller copepodites and nauplii, while the medium fraction contained mostly adult copepods and some decapod larvae.

Pulse events. During high rainfall events, environmental parameters were measured daily at sites close to the mouth of Kāne'ohe Stream (MP) as well as further offshore and out of the plume (OP). Rainfall data were obtained from the National Weather Service hydronet (www.prh.noaa.gov/hnl) and discharge data from the US Geological Service Kāne'ohe Stream gauge (http://waterdata.usgs.gov/nwis). The dispersion of the freshwater plume was estimated by measuring salinity of a shallow scoop of water from the sur-

the nearest geometrical shape (Edler 1979). Carbon (C) and nitrogen content (N) were estimated using a set of conversion factors selected from the literature (Table 1).

Zooplankton samples. Zooplankton was divided into large, medium and small size fractions. Triplicate samples were collected with $10 \mathrm{~m}$ vertical tows (approximately $1 \mathrm{~m} \mathrm{~s}^{-1}$ ) using a $35 \mu \mathrm{m}$ mesh net (30 cm diameter). Only NB, CB and SB sites were sampled, as MP was too shallow and time constraints prevented sampling at OCN. The entire sample from each $0.71 \mathrm{~m}^{3}$ tow was first poured onto a $183 \mu \mathrm{m}$ mesh and rinsed. This provided the $>183 \mu \mathrm{m}$ fraction (large fraction). This size fraction was not retained on the first 7 sampling dates. The fraction that passed through the $183 \mu \mathrm{m}$ mesh was split into 3 fractions. One was collected on a precombusted $25 \mathrm{~mm} \mathrm{GF/F} \mathrm{filter} \mathrm{for} \mathrm{CHN}$ analysis. The remaining sample was passed through a $63 \mu \mathrm{m}$ screen. Material retained was the <183>63 $\mu \mathrm{m}$ sample (medium fraction), while material passing though the screen was the $<63>35 \mu \mathrm{m}$ sample (small fraction). Each biomass sample was dried at $60^{\circ} \mathrm{C}$ overnight and reweighed. The biomass samples were combusted at $500^{\circ} \mathrm{C}$ for $4 \mathrm{~h}$ and reweighed to provide ash free dry mass (AFDM). Zooplankton biomass data are reported per $\mathrm{m}^{3}$ of Bay water sampled. The $\mathrm{CHN}$ samples were processed using the same methods as the water column CHN filters.

The large fraction included material that would not have been sampled in the water column sampling (as those samples were all prefiltered through a $183 \mu \mathrm{m}$ mesh). This sample usually consisted of chaetognaths, larger copepods and larval crustaceans, as well as occasional larval or juvenile fishes. Because the net diameter and mesh size were small, this fraction is probably not a quantitative sample of the fast-swimming zooplankton. The small fraction face layer (<10 cm depth) with a handheld YSI model 55 salinometer. Water for nutrient and plankton sampling was hand collected daily during events from subsurface waters ( $50 \mathrm{~cm}$ depth) at the MP site. Measurements of pico-, nano- and microplankton, dissolved inorganic nutrients, chl $a_{\text {, }}$ and particulate carbon and nitrogen were made from these water samples using the methods outlined above. During pulsed stream discharge events, chl a samples consisted of 3 replicate samples on $47 \mathrm{~mm}$ Whatman GF/F filters. To analyze total suspended solids (TSS), subsamples of approximately $250 \mathrm{ml}$ were filtered through pre-weighed and ashed GF/F filters for subsequent drying at $60^{\circ} \mathrm{C}$ for measurement of TSS. Pico-, nano- and microplankton were sampled during the April 2000, October 2000 and June 2001 pulse events. Data from pulse events were compared to baseline CISNet data (3 yr means from CISNet sampling period at the MP site).

Statistical analyses. Statistical analyses were performed using SAS. Data were transformed if necessary. Post-hoc tests following ANOVA used Duncan's test with $\alpha$ set at 0.05 .

\section{RESULTS}

\section{Spatial differences}

The most striking spatial difference in water column nutrients during the 3 yr study was the elevated nitrate concentration at the NB site compared to OCN, CB, SB and MP (Table 2). TDN was significantly lower at the OCN site, while MP had the highest concentration (Table 2). Dissolved organic nitrogen (DON, the difference between TDN and nitrate + ammonia) showed a gradual increase from $5.7 \mu \mathrm{M}$ at the $\mathrm{OCN}$ site to $8.3 \mu \mathrm{M}$ at the MP site. Silicate was significantly higher 
Table 2. Comparison of water column and plankton parameters (mean \pm SE) at sampling sites (OCN: oceanic site; NB: north bay; CB: central bay; SB: south bay; MP: mid plume). Letters in parentheses denote significant differences determined by Duncan's test. nd: no data; Chaetoceros was not found in the OCN samples

\begin{tabular}{|c|c|c|c|c|c|}
\hline & $\mathrm{OCN}$ & NB & CB & SB & MP \\
\hline \multicolumn{6}{|l|}{ Water column } \\
\hline Salinity (PSU) & $35.0 \pm 0.07$ (a) & $34.7 \pm 0.04(\mathrm{ab})$ & $35.0 \pm 0.04$ (a) & $35.1 \pm 0.04(\mathrm{a})$ & $34.3 \pm 0.22(\mathrm{~b})$ \\
\hline $\mathrm{N}$ & 5 & 71 & 71 & 71 & 59 \\
\hline $\operatorname{TSS}\left(\mathrm{mg} \mathrm{l}^{-1}\right)$ & $0.39 \pm 0.06(\mathrm{~d})$ & $2.7 \pm 0.22(b)$ & $1.9 \pm 0.12(\mathrm{c})$ & $2.0 \pm 0.10(\mathrm{bc})$ & $3.5 \pm 0.22(\mathrm{a})$ \\
\hline $\mathrm{N}$ & 8 & 71 & 71 & 71 & 59 \\
\hline Secchi depth (m) & $28 \pm 3.1(\mathrm{a})$ & $6.2 \pm 0.24(b)$ & $6.6 \pm 0.25(\mathrm{~b})$ & $5.4 \pm 0.20(\mathrm{~b})$ & $3.3 \pm 0.12(\mathrm{c})$ \\
\hline $\mathrm{N}$ & 6 & 70 & 70 & 70 & 57 \\
\hline \multicolumn{6}{|l|}{ Extinction } \\
\hline coefficient $\left(\mathrm{m}^{-1}\right)$ & $0.11 \pm 0.02(\mathrm{c})$ & $0.29 \pm 0.01(b)$ & $0.24 \pm 0.01(b)$ & $0.29 \pm 0.01(b)$ & $0.47 \pm 0.01(\mathrm{a})$ \\
\hline $\mathrm{N}$ & 4 & 62 & 62 & 62 & 54 \\
\hline Phosphate $(\mu \mathrm{M})$ & $0.09 \pm 0.01$ (a) & $0.07 \pm 0.005(\mathrm{~b})$ & $0.06 \pm 0.005(b)$ & $0.08 \pm 0.004(\mathrm{ab})$ & $0.71 \pm 0.004(b)$ \\
\hline Nitrate $(\mu \mathrm{M})$ & $0.05 \pm 0.02(b)$ & $0.28 \pm 0.04(\mathrm{a})$ & $0.09 \pm 0.03(\mathrm{ab})$ & $0.05 \pm 0.01(\mathrm{~b})$ & $0.20 \pm 0.08(\mathrm{ab})$ \\
\hline Ammonia $(\mu \mathrm{M})$ & $0.12 \pm 0.02$ (a) & $0.14 \pm 0.01$ (a) & $0.14 \pm 0.02$ (a) & $0.12 \pm 0.01$ (a) & $0.10 \pm 0.01$ (a) \\
\hline Silicate $(\mu \mathrm{M})$ & $2.3 \pm 0.22(\mathrm{c})$ & $7.1 \pm 0.20(b)$ & $5.0 \pm 0.24(\mathrm{bc})$ & $6.9 \pm 0.21(b)$ & $17 \pm 1.6(\mathrm{a})$ \\
\hline $\mathrm{N}$ & 8 & 72 & 72 & 72 & 51 \\
\hline TDP & $0.32 \pm 0.02(\mathrm{a})$ & $0.30 \pm 0.01(\mathrm{a})$ & $0.30 \pm 0.01(\mathrm{a})$ & $0.32 \pm 0.01(\mathrm{a})$ & $0.32 \pm 0.01(\mathrm{a})$ \\
\hline TDN & $5.9 \pm 0.53(\mathrm{c})$ & $7.0 \pm 0.24(b)$ & $7.2 \pm 0.24(\mathrm{~b})$ & $7.4 \pm 0.23(\mathrm{~b})$ & $8.6 \pm 0.35(\mathrm{a})$ \\
\hline DON & $5.7 \pm 0.53(\mathrm{bc})$ & $6.5 \pm 0.22(\mathrm{bc})$ & $6.9 \pm 0.25(b)$ & $7.2 \pm 0.23(b)$ & $8.1 \pm 0.29(\mathrm{a})$ \\
\hline $\mathrm{N}$ & 8 & 39 & 39 & 39 & 31 \\
\hline \multicolumn{6}{|l|}{ Particulate C \& N $\left(\mathrm{mg} \mathrm{m}^{-3}\right)$} \\
\hline PC total & $49 \pm 8.4(\mathrm{c})$ & $190 \pm 15(b)$ & $180 \pm 12(b)$ & $200 \pm 84(b)$ & $290 \pm 16(\mathrm{a})$ \\
\hline $\mathrm{PN}$ & $5.1 \pm 0.72(d)$ & $23 \pm 1.2(\mathrm{~b}, \mathrm{c})$ & $22 \pm 1.2(\mathrm{c})$ & $28 \pm 1.5(b)$ & $46 \pm 2.3(\mathrm{a})$ \\
\hline POC (acidified sample) & $54 \pm 14(\mathrm{c})$ & $140 \pm 11(\mathrm{~b})$ & $140 \pm 11(\mathrm{~b})$ & $170 \pm 8.0(\mathrm{~b})$ & $290 \pm 18(\mathrm{a})$ \\
\hline PN (acidified sample) & $5.9 \pm 1.3(\mathrm{~d})$ & $24 \pm 1.1(\mathrm{c})$ & $24 \pm 1.3(\mathrm{c})$ & $31 \pm 1.3(\mathrm{~b})$ & $49 \pm 2.7(\mathrm{a})$ \\
\hline $\mathrm{N}$ & 8 & 36 & 36 & 36 & 30 \\
\hline \multicolumn{6}{|l|}{$\mathrm{Chl} \mathrm{a}\left(\mathrm{mg} \mathrm{m}^{-3}\right)$} \\
\hline $0.2 \mu \mathrm{M}$ & $0.07 \pm 0.01(\mathrm{c})$ & $0.38 \pm 0.03(b)$ & $0.43 \pm 0.04(\mathrm{~b})$ & $0.56 \pm 0.03(\mathrm{ab})$ & $0.65 \pm 0.04(\mathrm{a})$ \\
\hline $2.0 \mu \mathrm{M}$ & $0.019 \pm 0.004(\mathrm{c})$ & $0.38 \pm 0.02(\mathrm{~b})$ & $0.26 \pm 0.02(\mathrm{~b})$ & $0.40 \pm 0.03(\mathrm{~b})$ & $0.90 \pm 0.09(\mathrm{a})$ \\
\hline Ratio $0.2: 2.0$ & $4.43 \pm 0.47(\mathrm{a})$ & $1.07 \pm 0.07(b)$ & $1.83 \pm 0.13(b)$ & $1.60 \pm 0.08(b)$ & $0.94 \pm 0.07(\mathrm{c})$ \\
\hline $\mathrm{GF} / \mathrm{F}$ & $0.094 \pm 0.012(\mathrm{c})$ & $0.65 \pm 0.03(b)$ & $0.60 \pm 0.04(\mathrm{~b})$ & $0.82 \pm 0.04(\mathrm{~b})$ & $1.4 \pm 0.01(\mathrm{a})$ \\
\hline $\mathrm{N}$ & 7 & 71 & 71 & 71 & 59 \\
\hline \multicolumn{6}{|l|}{ Plankton } \\
\hline \multicolumn{6}{|l|}{ Heterotrophic bacteria } \\
\hline $\mathrm{ml}^{-1}\left(\times 10^{6}\right)$ & $1.30 \pm 0.20(\mathrm{c})$ & $1.58 \pm 0.61(\mathrm{c})$ & $2.45 \pm 0.74(b)$ & $3.13 \pm 0.97(\mathrm{a})$ & $3.35 \pm 1.18(\mathrm{a})$ \\
\hline Prochlorococcus $\mathrm{ml}^{-1}\left(\times 10^{3}\right)$ & $254 \pm 115(\mathrm{a})$ & $3.80 \pm 2.60(\mathrm{~b})$ & 0 & 0 & 0 \\
\hline Synechococcus $\mathrm{ml}^{-1}\left(\times 10^{5}\right)$ & $0.08 \pm 0.05(\mathrm{~d})$ & $1.53 \pm 1.30(\mathrm{c})$ & $2.98 \pm 1.03(b)$ & $3.49 \pm 1.13(\mathrm{a}, \mathrm{b})$ & $3.64 \pm 1.41(\mathrm{a})$ \\
\hline Picoeukaryotes $\mathrm{ml}^{-1}\left(\times 10^{4}\right)$ & $0.22 \pm 0.10(\mathrm{~d})$ & $1.17 \pm 0.50(\mathrm{c})$ & $1.81 \pm 0.85(\mathrm{c})$ & $2.86 \pm 1.31(\mathrm{~b})$ & $3.20 \pm 1.60(\mathrm{a})$ \\
\hline Nanoeukaryotes $\mathrm{ml}^{-1}$ & $24 \pm 5(\mathrm{c})$ & $265 \pm 158(b)$ & $264 \pm 199(b)$ & $325 \pm 294(b)$ & $615 \pm 368$ (a) \\
\hline $\mathrm{N}$ & 15 & 96 & 96 & 96 & 96 \\
\hline \multirow{2}{*}{$\begin{array}{l}\text { Pennate diatoms } l^{-1} \\
\text { size }(\mu \mathrm{m})\end{array}$} & $142 \pm 103(b)$ & $3840 \pm 2550$ (a) & $1040 \pm 943(b)$ & $2040 \pm 1580(a, b)$ & $3650 \pm 3560$ (a) \\
\hline & $34 \pm 23(b)$ & $54 \pm 32(\mathrm{a}, \mathrm{b})$ & $49 \pm 10(a, b)$ & $77 \pm 47(\mathrm{a})$ & $75 \pm 37$ (a) \\
\hline \multirow{2}{*}{$\begin{array}{l}\text { Chaetoceros } \mathrm{l}^{-1} \\
\text { size }(\mu \mathrm{m})\end{array}$} & 0 & $602 \pm 2580(\mathrm{a})$ & $105 \pm 219$ (a) & $363 \pm 419(a)$ & $879 \pm 2440$ (a) \\
\hline & nd & $10 \pm 6(\mathrm{a})$ & $12 \pm 7(\mathrm{a})$ & $11 \pm 9(\mathrm{a})$ & $15 \pm 12(\mathrm{a})$ \\
\hline \multirow{2}{*}{$\begin{array}{l}\text { Dinoflagellates } \mathrm{l}^{-1} \\
\text { size }(\mu \mathrm{m})\end{array}$} & $2410 \pm 1070(\mathrm{a})$ & $2620 \pm 2020(\mathrm{a})$ & $2330 \pm 1850(\mathrm{a})$ & $2930 \pm 2360(\mathrm{a})$ & $2180 \pm 1190(\mathrm{a})$ \\
\hline & $16 \pm 7(\mathrm{a})$ & $21 \pm 9$ (a) & $23 \pm 10(\mathrm{a})$ & $22 \pm 8(\mathrm{a})$ & $22 \pm 9$ (a) \\
\hline \multirow{2}{*}{$\begin{array}{l}\text { Ciliates }{ }^{-1} \\
\text { size }(\mu \mathrm{m})\end{array}$} & $818 \pm 445(\mathrm{a})$ & $636 \pm 586(a)$ & $418 \pm 252(\mathrm{a})$ & $609 \pm 691(\mathrm{a})$ & $619 \pm 667(\mathrm{a})$ \\
\hline & $26 \pm 7(\mathrm{a})$ & $21 \pm 8(\mathrm{a})$ & $28 \pm 11(\mathrm{a})$ & $25 \pm 13(\mathrm{a})$ & $26 \pm 15(\mathrm{a})$ \\
\hline $\mathrm{N}$ & 10 & 30 & 30 & 30 & 30 \\
\hline \multicolumn{6}{|l|}{ Zooplankton (mg m${ }^{-3}$ ) } \\
\hline \multirow[t]{2}{*}{ Large $>183 \mu \mathrm{m}$} & & $11.0 \pm 5.83(\mathrm{c})$ & $14.7 \pm 6.00(b)$ & $19.8 \pm 5.41(\mathrm{a})$ & \\
\hline & & 32 & 32 & 32 & \\
\hline Medium $<183>63 \mu \mathrm{m}$ & & $16.4 \pm 7.77(\mathrm{c})$ & $21.2 \pm 10.0(b)$ & $32.6 \pm 8.20(\mathrm{a})$ & \\
\hline Small <63 $\mu \mathrm{m}$ & & $16.9 \pm 5.32(\mathrm{a})$ & $10.6 \pm 3.00(b)$ & $12.9 \pm 3.39(b)$ & \\
\hline $\mathrm{N}$ & & 39 & 39 & 39 & \\
\hline
\end{tabular}


at $\mathrm{MP}>\mathrm{NB}=\mathrm{SB}>\mathrm{CB}=\mathrm{OCN}$. The other inorganic nutrients measured (phosphate, TDP, ammonia) were not significantly different among sites (Table 2). Chl a also showed some among-site differences: for the $0.2 \mu \mathrm{m}$ fraction, $\mathrm{MP}=\mathrm{SB}>\mathrm{CB}=\mathrm{NB}>\mathrm{OCN}$ for the $2.0 \mu \mathrm{m}$ fraction, $\mathrm{MP}>\mathrm{SB}=\mathrm{NB}=\mathrm{CB}>\mathrm{OCN}$; and for the $\mathrm{GF} / \mathrm{F}$ fraction, $\mathrm{MP}>\mathrm{SB}=\mathrm{NB}=\mathrm{CB}>\mathrm{OCN}$ (Table 2). The ratio between the small and large chl a fractions also showed significant differences with $\mathrm{OCN}>\mathrm{CB}=$ $\mathrm{SB}=\mathrm{NB}>\mathrm{MP}$ (Table 2).

Significant differences in picoplankton abundances were found among sites (Table 2$)$. Mean $( \pm \mathrm{SE})$ cell size was $0.5 \pm 0.3 \mu \mathrm{m}$ for heterotrophic bacteria, $1.2 \pm$ $0.6 \mu \mathrm{m}$ for Synechococcus, $1.4 \pm 0.3 \mu \mathrm{m}$ for picoeukaryotes, and $3.3 \pm 0.7 \mu \mathrm{m}$ for nanoeukaryotes. A general trend was observed with an increase in cell abundance from $\mathrm{OCN}<\mathrm{NB}<\mathrm{CB}<\mathrm{SB}<\mathrm{MP}$ (Table $2 \mathrm{~b}$ ). The oceanic site had the lowest concentrations of all cell types except Prochlorococcus. Prochlorococcus was the dominant picoplankton at the oceanic site $\left(2.54 \times 10^{5}\right.$ cells $\mathrm{ml}^{-1}$ ) but was only detectable within Kāne'ohe Bay at the NB site $\left(3.8 \times 10^{3}\right.$ cells $\left.\mathrm{ml}^{-1}\right)$. Oceanic values for Synechococcus were significantly different from the Bay sites, even though these sites are connected by the channels and water flowing over the barrier reef. Within Kāne'ohe Bay, NB had the lowest abundance of most cell types and MP the highest (Table 2). Microplankton also showed significant spatial differences in abundances in pennate diatoms but not in other groups (Table 2). There were no significant spatial differences in cell size for microplankton, although there was a general trend of smallest size at OCN site and largest size at SB and MP (Table 2).

ANOVA indicated significant differences among the 3 sites sampled for zooplankton biomass for the large and medium fractions, with $\mathrm{SB}>\mathrm{CB}>\mathrm{NB}$ (Table 2). The small fraction was greatest at NB, while $\mathrm{CB}$ and $\mathrm{SB}$ were not significantly different from each other (Table 2).

\section{Carbon and nitrogen content at different sites}

Particulate carbon and nitrogen content of the pico-, nano-, and microplankton at the different sites was calculated from the number and size of cells using conversion factors (Table 1). Within Kāne'ohe Bay and oceanic sites, there was an increase in microbial carbon and nitrogen from $\mathrm{OCN}<\mathrm{NB}<\mathrm{CB}<\mathrm{SB}<\mathrm{MP}$. At the 3 sites where all plankton fractions (from pico- to zooplankton) were measured (NB, $\mathrm{CB}, \mathrm{SB})$, picoplankton was the dominant fraction in terms of carbon (79 to $88 \%$ ) and nitrogen (76 to $83 \%$, Fig. 2). At all sites, picoplankton populations represented more than $90 \%$ of total microbial carbon and nitrogen. Picoplankton
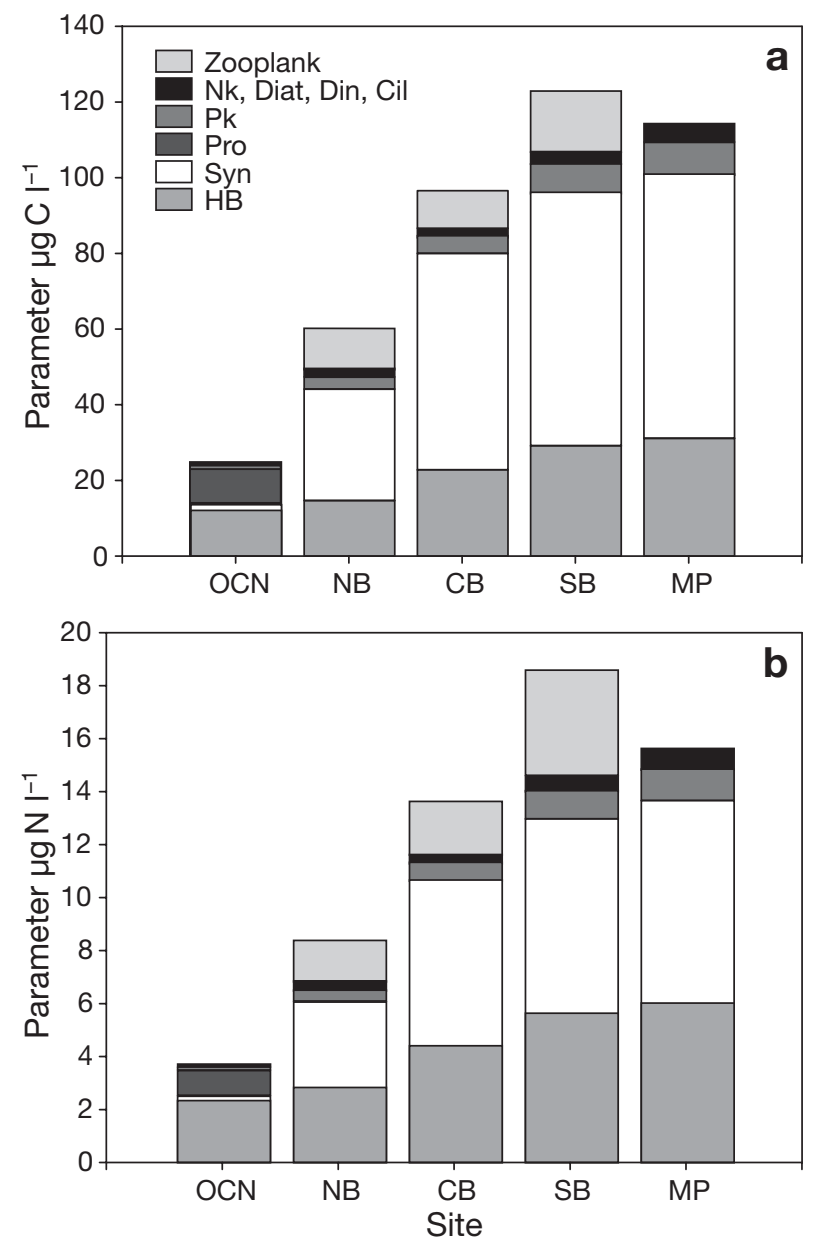

Fig. 2. (a) Carbon and (b) nitrogen content of plankton. Values for microbial plankton derived by cell conversion factors (see 'Materials and methods'), for zooplankton from CHN analysis of dried samples (NB: zooplankton not sampled at OCN or MP sites). Zooplank: zooplankton; Nk: nanoenkaryotes; Diat: diatoms; Din: dinoflagellates; Cil: ciliates; Pk: picoenkaryotes; Pro: Prochlorococcus spp.; Syn: Synechococcus spp.; HB: heterotrophic bacteria. Site abbreviations as in Fig. 1

carbon and nitrogen at the oceanic site was mainly in heterotrophic bacteria (more than $50 \%$ of carbon and nitrogen), with Prochlorococcus cells contributing $40 \%$ of the picoplankton carbon and $28 \%$ of the nitrogen. The dominant component within Kāne'ohe Bay was Synechococcus, accounting on average for more than $50 \%$ of the picoplankton carbon and nitrogen (Fig. 2).

The particulate carbon and nitrogen content of the water column as estimated from cell count-sizeconversion factors was compared to the carbon and nitrogen measured from water column samples (see 'Materials and methods'), where total carbon included both inorganic and organic particulate carbon. An estimation of organic particulate carbon was obtained by acidification treatment to remove carbonates. Carbon values from the water column samples (total and 

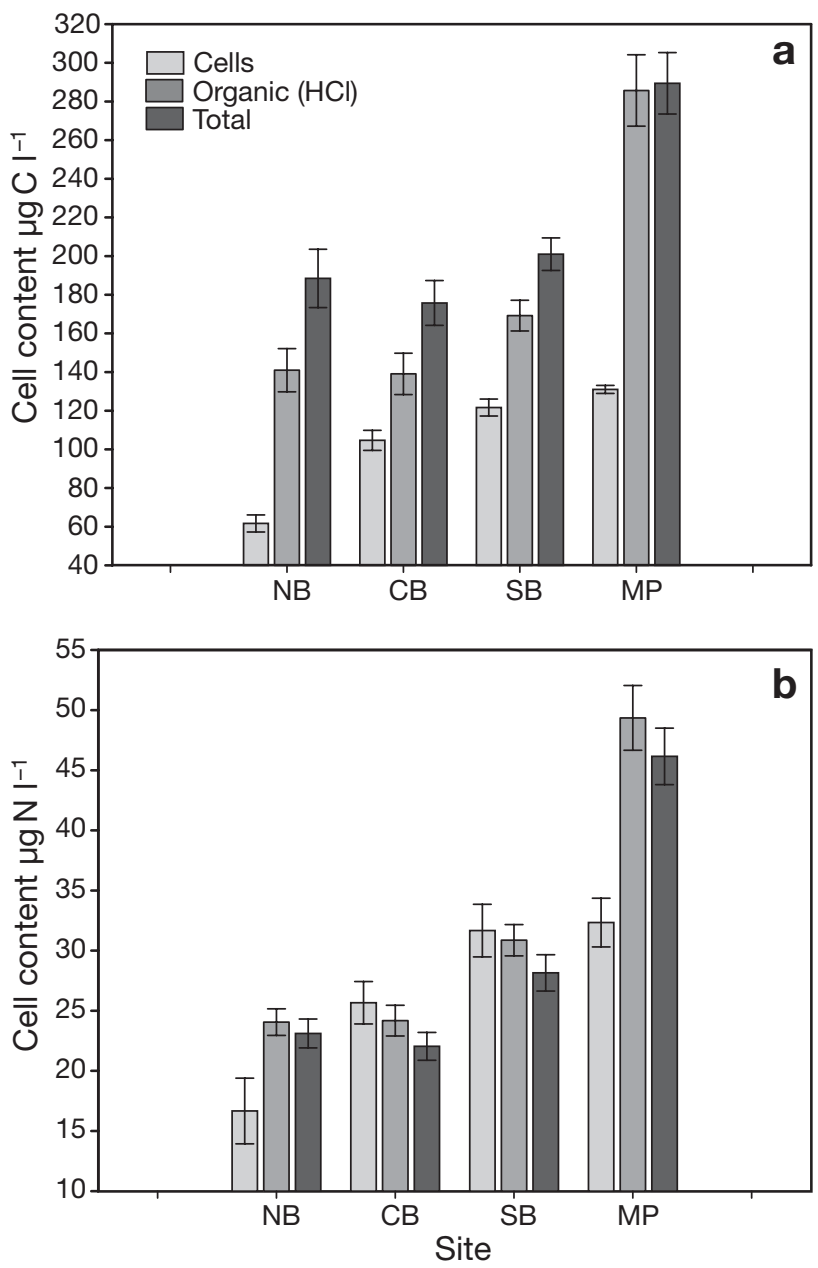

Fig. 3. Comparison of (a) particulate carbon and (b) particulate nitrogen as estimated by the cell conversion method (light gray bars) and water column samples (black bars: samples rinsed with deionized water only; dark gray bars: samples rinsed with hydrochloric acid). Site abbreviations as in Fig. 1

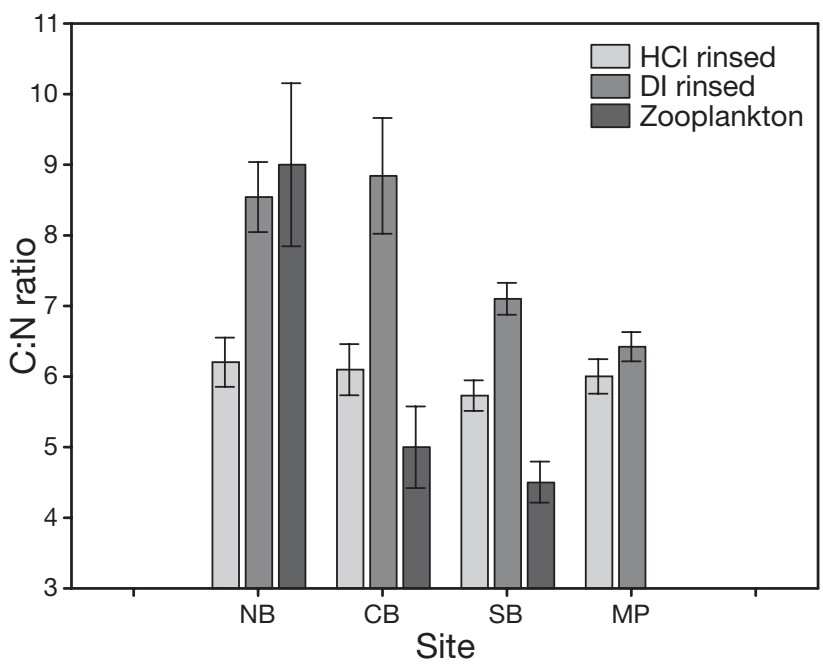

Fig. 4. C:N ratios for water column and zooplankton samples. Site abbreviations as in Fig. 1

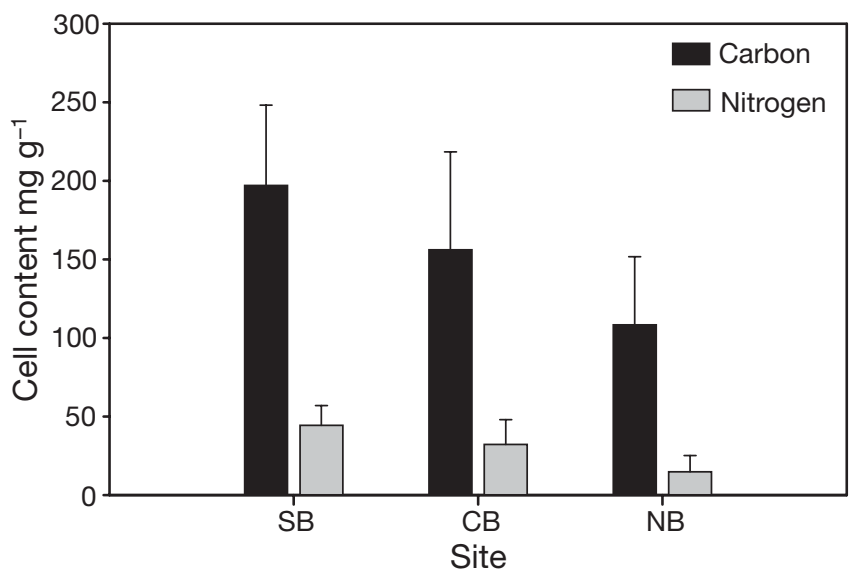

Fig. 5. Zooplankton carbon and nitrogen normalized to zooplankton dry mass. Site abbreviations as in Fig. 1

organic) were significantly higher than the cell countsize-conversion factor method (Fig. 3a). There were no significant differences between total nitrogen and nitrogen after acidification at any site. Nitrogen values calculated by analysis of particulates in filtered water and count-size-conversion factors were the same at the $\mathrm{CB}$ and SB sites, but the NB and MP sites showed higher values in water column samples (Fig. 3b), which suggests that detritus represented about $30 \%$ of particulate nitrogen in these samples, reflecting the proximity of streams as was also seen in the lower salinity and higher TSS at these sites (Table 2). C:N ratios were higher for non-decalcified samples with values ranging from $6.4(\mathrm{MP})$ to $8.8(\mathrm{CB})$. When samples were rinsed with $\mathrm{HCl}$, the $\mathrm{C}: \mathrm{N}$ ratios were close to 6 at all sites (Fig. 4), similar to marine plankton rations (Atkinson \& Smith 1983); this suggests that detritus was probably not from benthic macroalgae, in which case $\mathrm{C}: \mathrm{N}$ ratios would have been much higher.

Zooplankton samples showed that carbon and nitrogen values ranged from 10 to $15 \mu \mathrm{gC} \mathrm{l}^{-1}$ and from 2 to $4 \mathrm{\mu g} \mathrm{N} \mathrm{l}^{-1}$ (Fig. 2), which represented about 10 to $17 \%$ of the carbon and 15 to $22 \%$ of the nitrogen at NB, CB and SB where all fractions were analyzed. When zooplankton carbon and nitrogen content were normalized to zooplankton dry mass, there were significant differences in both carbon and nitrogen content, with $\mathrm{SB}>\mathrm{CB}>\mathrm{NB}$ (Fig. 5).

\section{Temporal differences}

There were no obvious seasonal patterns in nutrient levels throughout the $3 \mathrm{yr}$ CISNet sampling program at any of the 4 main study sites (www.hawaii.edu/cisnet). This project took place during a drought on $\mathrm{O}^{\prime} \mathrm{ahu}$, with stream discharge substantially below long-term 
mean daily discharge (for example, US Geological Survey data for Kāne'ohe Stream: 1976-2001, mean daily discharge $0.286 \mathrm{~m}^{3} \mathrm{~s}^{-1}$; CISNet study: 1998-2001, mean daily discharge $0.142 \mathrm{~m}^{3} \mathrm{~s}^{-1}$ ).

However, if the CISNet data were simply grouped into dry and wet seasons (dry: June to September; wet: October to May), we did find some significant differences in nutrient concentrations within Kāne'ohe Bay. Phosphate and TDP were higher during the wet season
(Table 3). Significantly higher nitrate concentrations during the wet season were only found at the NB site. In contrast, higher silicate concentrations during the dry season were found at the CB and SB sites (Table 3). The $0.2 \mu \mathrm{m}$ chl a fraction was significantly higher in the dry season at the NB, CB and SB sites, but all other chl $a$ fractions and the ratio of small to large chl a showed no significant dry versus wet season differences (Table 3). The microbial groups also showed significant differ-

Table 3. Comparison of water column and plankton parameters (mean \pm SE) during dry and wet seasons in Kāne'ohe Bay. Site abbreviations as in Fig. 1. Values in bold are significantly higher than those of the alternate season for that site. Site abbreviations as in Fig. 1

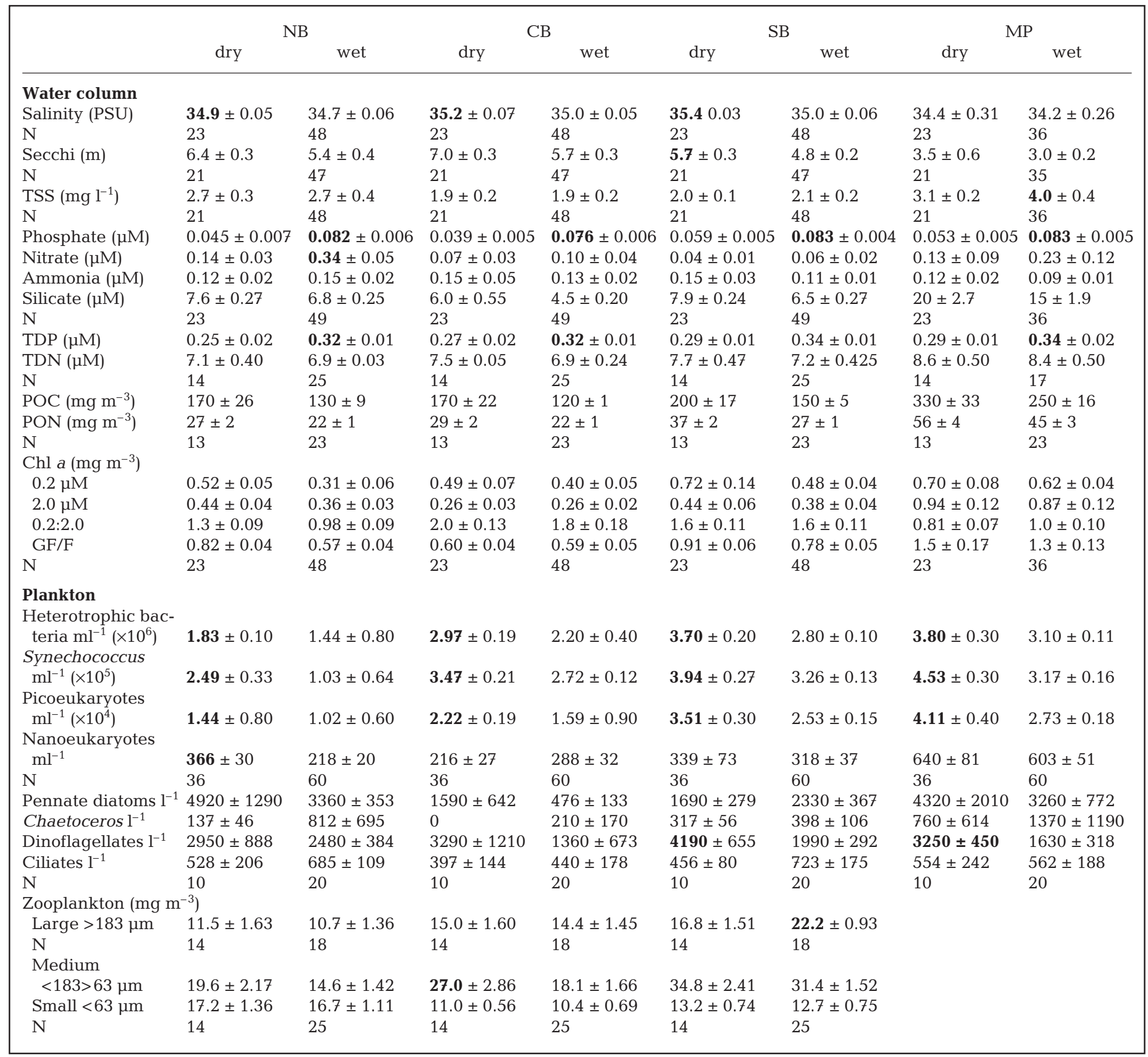


ences, with higher concentrations of heterotrophic bacteria, Synechococcus, and picoeukaryotes during the dry season (Table 3). For larger cells, the only significant dry versus wet season differences occurred in dinoflagellate abundances at the SB and MP sites (Table 3b). Zooplankton showed higher biomass (AFDM) during the dry season in the large fraction at $\mathrm{SB}$, and in the medium fraction at CB (Table 3).

\section{General pulse features}

All pulses of rainfall and increased discharge measured during this period resulted in a plume of brown, turbid water in southern Kāne'ohe Bay. The MP site was within this brown plume during all pulses, as evidenced by dramatically-decreased surface salinity and increased TSS at the beginning of each pulse (Table 4). The duration and extent of the brown plume depended on the amount and timing of increased discharge as well as additional factors, such as wind speed/direction and strength of tidal flushing. All pulses resulted in increased nitrate and TDN, correlated with lowered salinity (Fig. 6: nitrate $\mathrm{r}^{2}=0.79$, data from all pulses combined; TDN $\mathrm{r}^{2}$ $=0.83)$. Likewise, phosphate $\left(\mathrm{r}^{2}=0.50\right)$, TDP $\left(\mathrm{r}^{2}=0.49\right)$, and silicates $\left(r^{2}=0.83\right)$ also showed an increase following pulses, correlated with decreased salinity (Fig. 6). $\mathrm{Chl}$ a typically peaked in concentration 3 to $7 \mathrm{~d}$ following the initial nutrient inputs. The same pattern was also observed in microphytoplankton groups, specifically in the Chaetoceros genus, but not in picoplankton. Picoplanktonic cell abundance did not show a large increase, except following the dry season pulse (June 2001). However, fluorescence for Synechococcus (dominant picophytoplankton group) showed an increase 12 to $24 \mathrm{~h}$ after rain discharge (Fig. 7), suggesting an increase in pigments per cell.

\section{Individual pulse histories}

\section{January 2000 pulse}

Heavy rains occurred during the evening of January 19 , resulting in over $80 \mathrm{~mm}$ of rainfall in $24 \mathrm{~h}$ as recorded at the Luluku rain gauge. Discharge from Kāne'ohe Stream increased to $1.84 \mathrm{~m}^{3} \mathrm{~s}^{-1}$ (Fig. 8). Surface salinity at the MP site on January 20 dropped to 12 PSU, with salinity at $0.5 \mathrm{~m}$ at 27 PSU. Nitrate con- centrations on the morning of January 20 were $16 \mu \mathrm{M}$ (87 times baseline), phosphate increased to $0.57 \mu \mathrm{M}$ (8 times baseline), and silicate increased to $121 \mu \mathrm{M}$ and remained elevated for 5 days (Fig. 8). Chl a peaked at $4.9 \mathrm{\mu g} \mathrm{l}^{-1}, 3$ days following the pulse (Fig. 8). Nitrate and TDN concentrations increased at the OP site, but only following the second rain and discharge event (January 27, Fig. 9). Chl a at the OP site had increased 3 -fold by 5 days after the first discharge pulse. No microbial samples were collected during this pulse.

April 2000 pulse

Rainfall on March 31 and April 1 (59 mm in 24 h) increased stream discharge to $0.57 \mathrm{~m}^{3} \mathrm{~s}^{-1}$ (Fig. 8). Surface salinity at MP on March 31 dropped to 19 PSU, while at $0.5 \mathrm{~m}$ depth it was 34 PSU. By April 1, salinity was $21 \mathrm{PSU}$ at $0.5 \mathrm{~m}$ depth; by April 3, surface salinity had returned to approximately 31 PSU. Following the initial pulse, nitrate concentration at MP increased to $9.8 \mu \mathrm{M}$ (52 times baseline) and phosphate to $0.39 \mu \mathrm{M}$ (6 times baseline) (Fig. 8). Silicate remained elevated for 6 days following the initial discharge pulse. Chl a lagged the nutrient increase, peaking at $5.9 \mu \mathrm{g} \mathrm{I}^{-1}$ 6 days after the pulse (Fig. 8) There were small increases in nitrate (to $0.92 \mu \mathrm{M}$ ) and phosphate (to $0.13 \mu \mathrm{M}$ ) at the OP site (Fig. $9 \&$ Table 4).

A second period of rainfall on April 9 (26 mm) elevated stream discharge to $0.24 \mathrm{~m}^{3} \mathrm{~s}^{-1}$. This was accompanied by a small decrease in surface salinity to 

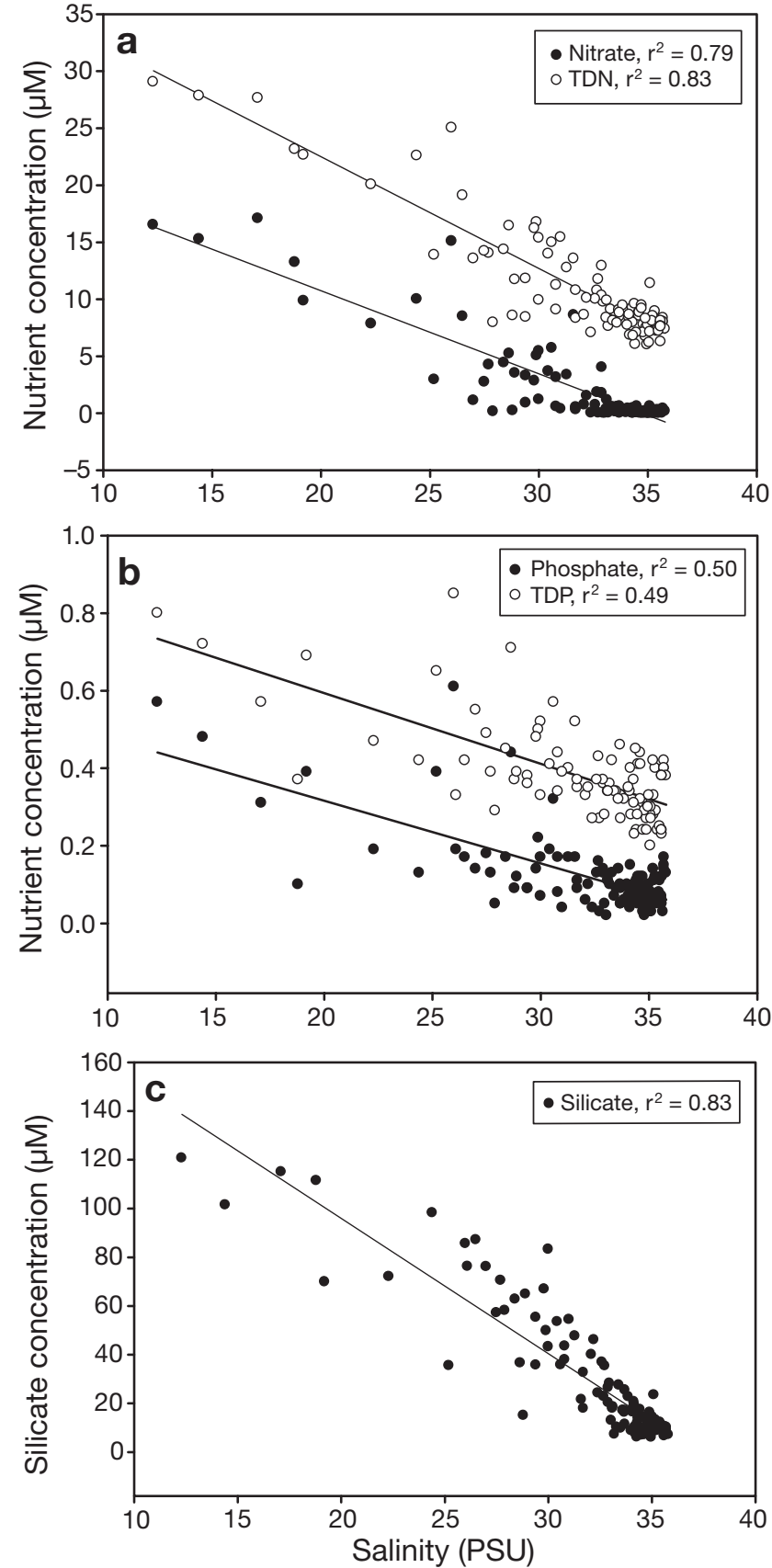

Fig. 6. Relationship between salinity and water column parameters (a) nitrogen, (b) phosphorus and (c) silicate during $1.5 \mathrm{yr}$ time-period of pulse sampling. TDN: total dissolved nitrogen; TDP: total dissolved phosphorus

28 PSU that persisted for several days. Increases in nitrate (to $5.4 \mu \mathrm{M}$ ) and phosphate (to $0.18 \mu \mathrm{M}$ ) lagged the second discharge pulse by $3 \mathrm{~d}$. At the OP site there was a small increase in nitrate 6 days after the secondary discharge pulse (Fig. 9).

Microbial sampling began on April 3, 2 days after the initial stream pulse. The initial low abundance of heterotrophic bacteria and Synechococcus may have been due

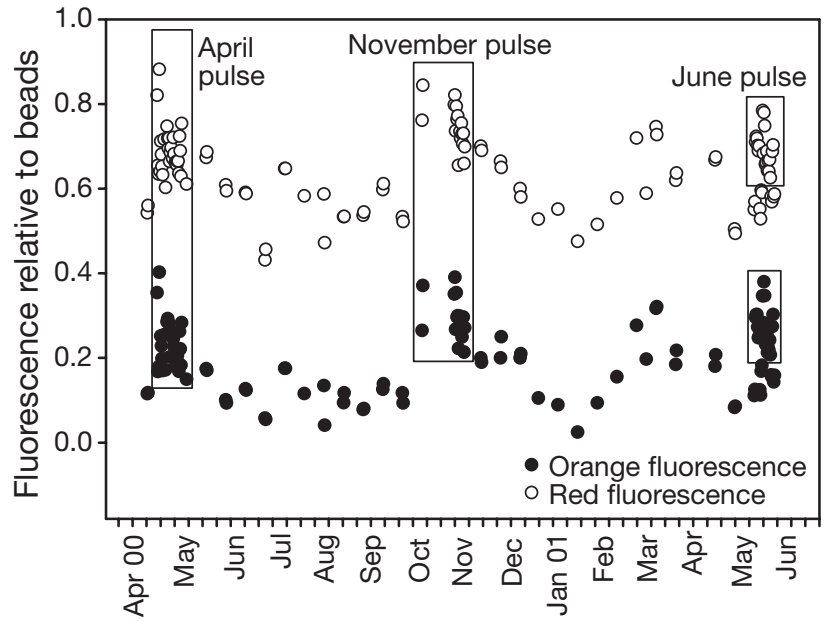

Fig. 7. Synechococcus spp. Average autofluorescence signals relative to beads fluorescence by samples run in flowcytometer. Orange fluorescence: chlorophyll; red fluorescence: phycoerythrin. Pulse data is boxed

to flushing and dilution. Abundance also dropped following the second stream discharge on April 9 (Fig. 10). In contrast, nanoeukaroytes at the MP site were elevated above baseline during this pulse (Fig. 10). Counts for microplankton showed a lagged increase in abundance following the stream discharge pulse. The genus Chaetoceros responded the most dramatically, with a very large increase in cell number 5 days following the initial pulse (Fig. 11). Pennate diatoms, dinoflagellates, and ciliates also showed a lagged response (5 to $10 \mathrm{~d}$ ) following the initial stream pulse and showed their highest abundances following the second discharge pulse (Fig. 11). Microbial cell counts at OP generally overlapped with cell counts at the MP site (Fig. 10).

\section{October 2000 pulse}

Following 2 days of rain on October 29 and 30 (total $71 \mathrm{~mm}$ ), discharge increased to $0.62 \mathrm{~m}^{3} \mathrm{~s}^{-1}$ (Fig. 8). Sub-surface salinity decreased to $29 \mathrm{PSU}$, and nitrate increased to $5.2 \mu \mathrm{M}$ (28 times baseline) and phosphate to $0.44 \mu \mathrm{M}$ (6 times baseline) (Fig. 8). Silicate rose to $37 \mu \mathrm{M}$, and remained elevated for most of the sampling period. Chl a peaked at $1.9 \mathrm{\mu g} \mathrm{l}^{-1}, 3$ days following the initial pulse.

An additional $56 \mathrm{~mm}$ of rain fell on November 3, increasing stream discharge to $1.3 \mathrm{~m}^{3} \mathrm{~s}^{-1}$. Although sampling commenced on November 3, the drop in salinity and increase in nitrate (19 times baseline) and phosphate (3 times baseline) were not recorded at the MP site until November 7 (Fig. 8). The second discharge was $79 \%$ of the rain discharged during the initial $2 \mathrm{~d}$ pulse, and although the nitrate increase was $70 \%$ of the initial pulse of nitrate, the phosphate was only $43 \%$ 

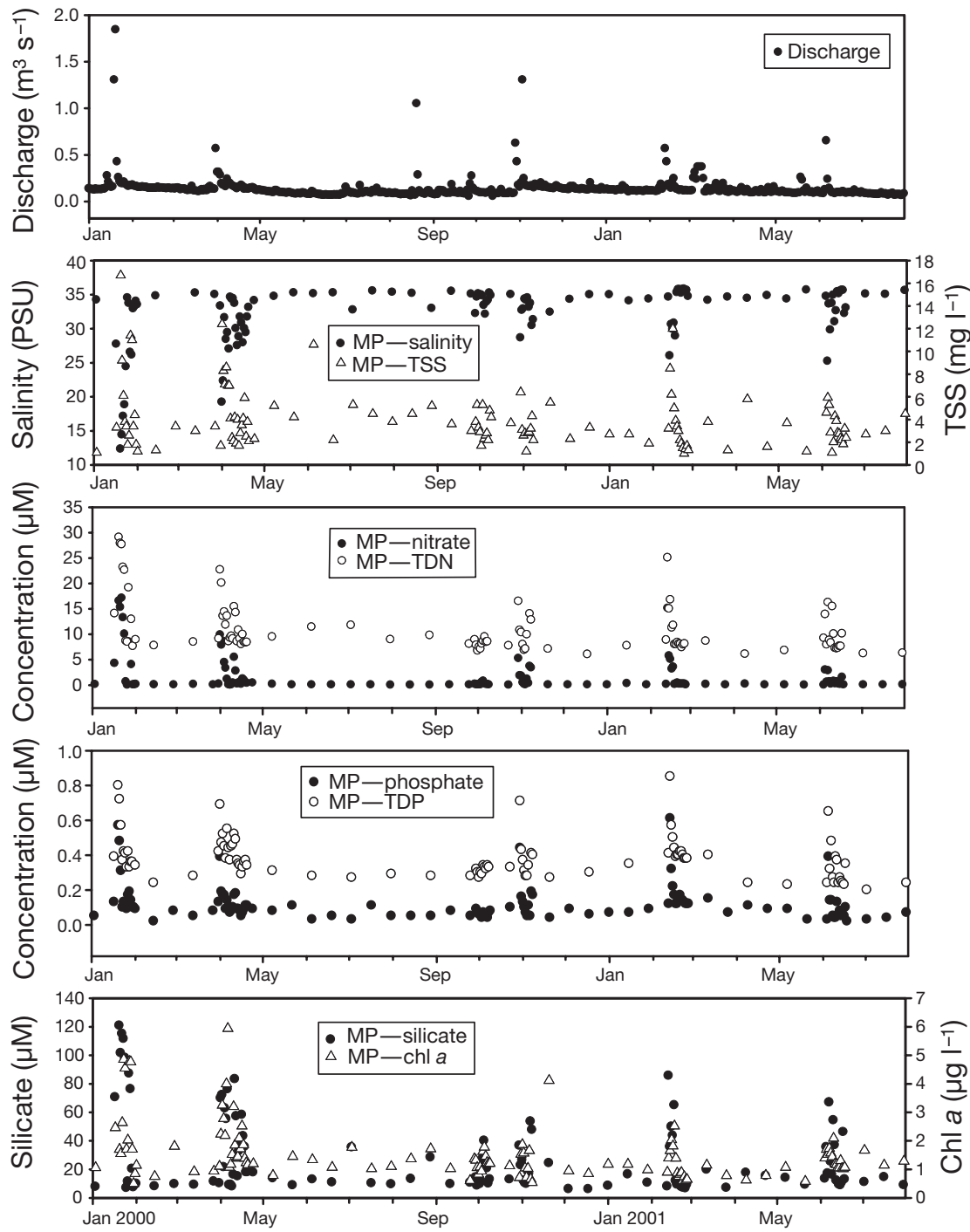

Fig. 8. Water column parameters at mid plume (MP) site during pulsesampling period. Discharge at Kāne'ohe Stream gauge (US Geological Service data) indicates the pulses followed (NB: August 2000 pulse was not sampled)

of the initial phosphate discharged during the earlier pulse. Only pico- and nanoplankton were sampled from October 31 to November 8 . These plankton groups did not show strong responses to the pulse (Fig. 10), which were within the range of baseline values.

February 2001 pulse

February 12 was a regular CISNet sampling day. On February 13, $63 \mathrm{~mm}$ of rainfall were recorded at the Luluku gauge, associated with an increase in stream discharge to $0.57 \mathrm{~m}^{3} \mathrm{~s}^{-1}$ (Fig. 8). Subsurface salinity dropped from 34 PSU on February 12 to 26 PSU on February 13, and gradually returned to 34 PSU by
February 18. Nitrate jumped from $0.14 \mu \mathrm{M}$ during CISNet sampling (February 12) at $\mathrm{MP}$ to $15 \mu \mathrm{M}$ on the following day. Likewise, phosphate increased from $0.12 \mu \mathrm{M}$ during the CISNet sampling to $0.61 \mu \mathrm{M}$. Silicate increased from $8 \mu \mathrm{M}$ to $86 \mu \mathrm{M}$. Chl a peaked at $2.5 \mu \mathrm{g}^{-1}$ approximately 5 days following the nutrient peak, but returned quickly to baseline levels (Fig. 8). At the OP site, there was a slight increase in nitrate following the discharge but no significant changes in phosphate, silicate or chl a (Fig. 9). No microbial data were collected during this pulse.

\section{June 2001 pulse}

June 4, a regular CISNet sampling date, was followed by 2 days of rain, producing a $2 \mathrm{~d}$ sum of $51 \mathrm{~mm}$ at the Luluku rain gauge. Stream discharge peaked briefly at $0.61 \mathrm{~m}^{3} \mathrm{~s}^{-1}$ but rapidly returned to baseline levels (Fig. 8). Subsurface salinity dropped to 25 PSU, but returned to 34 PSU by June 8. Nitrate peaked at $2.95 \mu \mathrm{M}$ (16 times baseline) and phosphate peaked at $0.39 \mu \mathrm{M}$ (6 times baseline) (Fig. 8). Silicate peaked at $67 \mu \mathrm{M}$ on June 7. Chl a peaked at $2.1 \mu \mathrm{g} \mathrm{l}{ }^{-1}$, 6 days following the start of the event. There were no major changes in nitrate, phosphate, silicate or chl a at the OP site (Fig. 9).

There were several smaller rain events following the initial pulse, leading to a small increase in stream discharge on June 17, accompanied by a decrease in subsurface salinity to 32 PSU and an increase in nitrate $(1.52 \mu \mathrm{M})$, phosphate $(0.10 \mu \mathrm{M})$ and silicate $(46 \mu \mathrm{M})$.

Picoplankton concentrations were above baseline values following the discharge pulse (Fig. 10). Diatoms and dinoflagellates showed only small increases above baseline values; however, ciliate concentrations reached 12 times the overall mean 5 days after the peak discharge (Fig. 11).

\section{DISCUSSION}

\section{Spatial differences}

Kāne'ohe Bay receives 2 main sources of allocthonous water, freshwater inputs and oceanic water, that flush the Bay. The effect of runoff from the main streams of Kāne'ohe represents an input of new nutri- 

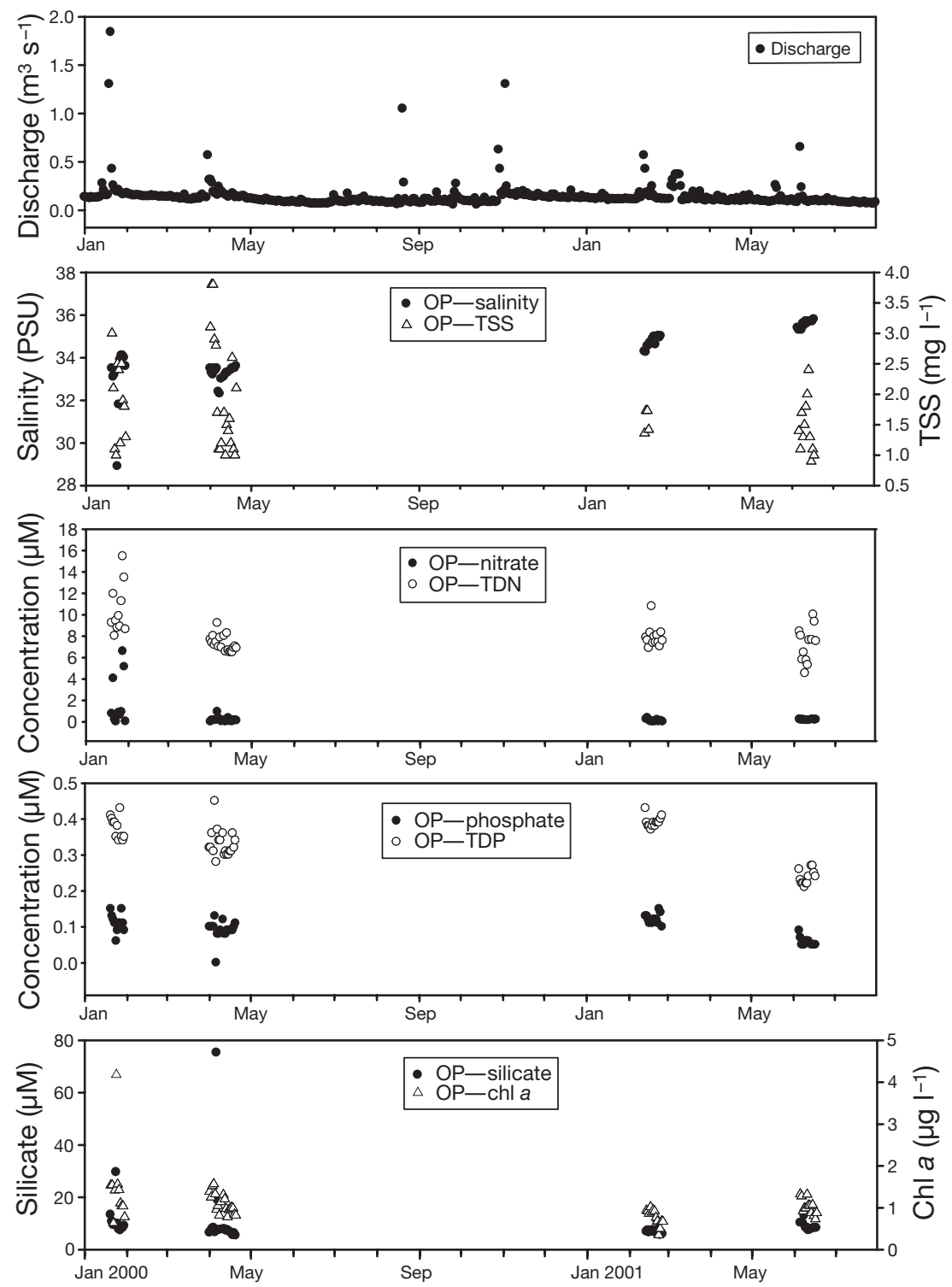

Fig. 9. Water column parameters at outside plume (OP) site during pulsesampling period. Discharge at Kāne'ohe Stream gauge (US Geological Service data) indicates the pulses followed (NB: August, October and November 2000 pulses were not sampled)

ents to the Bay and, in contrast, the flushing with oceanic water dilutes the Bay water. However, average nutrient concentrations within Kāne'ohe Bay were (with some exceptions) not different from the oceanic values measured in this study. In general, nutrient concentrations within the Bay were low, possibly due to the drought that coincided with our sampling period. The exceptions to the low water column nutrient levels within the Bay were nitrate at the NB site, silicate at the $\mathrm{MP}, \mathrm{SB}$, and NB sites, and TDN at the MP, SB and CB sites. NB receives the greatest flushing with oceanic water; however, this site still had the highest nitrate levels, demonstrating the importance of input from
Waikãne and Wai`hole streams emptying into the Bay near the NB site (Fig. 1). Higher silicate concentrations also reflected freshwater inputs. Increased nitrogen may also be associated with the efficient trapping, consumption and remineralization of particulate organic matter by reef biota (Ribes et al. 2005), decomposition in the pore space of the sand and reef framework (Rasheed et al. 2002), or nitrogen fixation by organisms living in the reef environment (Capone 1983, D'Elia \& Wiebe 1990, Williams \& Carpenter 1998).

All plankton cell types and total plankton biomass (in carbon and nitrogen units) gradually increased in the order $\mathrm{OCN}<$ $\mathrm{NB}<\mathrm{CB}<\mathrm{SB}<\mathrm{MP}$. There was a clear dominance of picoplankton in terms of cell concentrations and biomass, typical of oligotrophic systems such as coral reefs. Picoplankton have been previously reported to account for 40 to $45 \%$ of the biomass of phytoplankton in Kāne'ohe Bay (Taguchi \& Laws 1989, Laws \& Allen 1996). Our sampling period occurred during a drought, and picoplankton constituted more than $90 \%$ of the phytoplankton community, reflecting the dominance of this size class during low nutrient conditions. The zooplankton fraction was about 10 to $20 \%$ of the total plankton biomass, reflecting a planktonic community composition dominated by components $<20 \mu \mathrm{m}$, typical of oligotrophic systems such as coral reefs. Dominance of smallsized prokaryotic phytoplankton in terms of biomass and primary production has been also reported for atoll lagoons (Charpy 1996, Charpy \& Blanchot 1998) and tropical coastal ecosystems adjacent to high islands (Tada et al. 2003, Agawin et al. 2003).

The switch in dominance of the cyanobacteria from Prochlorococcus at the oceanic site to Synechococcus in Kāne'ohe Bay was the most characteristic feature of plankton distribution in our study. A similar dominance of Synechococcus in atoll lagoons and Prochlorococcus in the surrounding ocean waters has been reported on French Polynesian reefs (Charpy \& Blanchot 1998). Nitrogen availability and source and light intensity and spectral quality have been discussed as the main factors controlling marine cyanobacteria abundance (Kana \& Glibert 1987, Moore et al. 1995, 2002, Ting et al. 2002). Prochlorococcus may be insensitive to changes in nutrient concentration, whereas Synecho- 

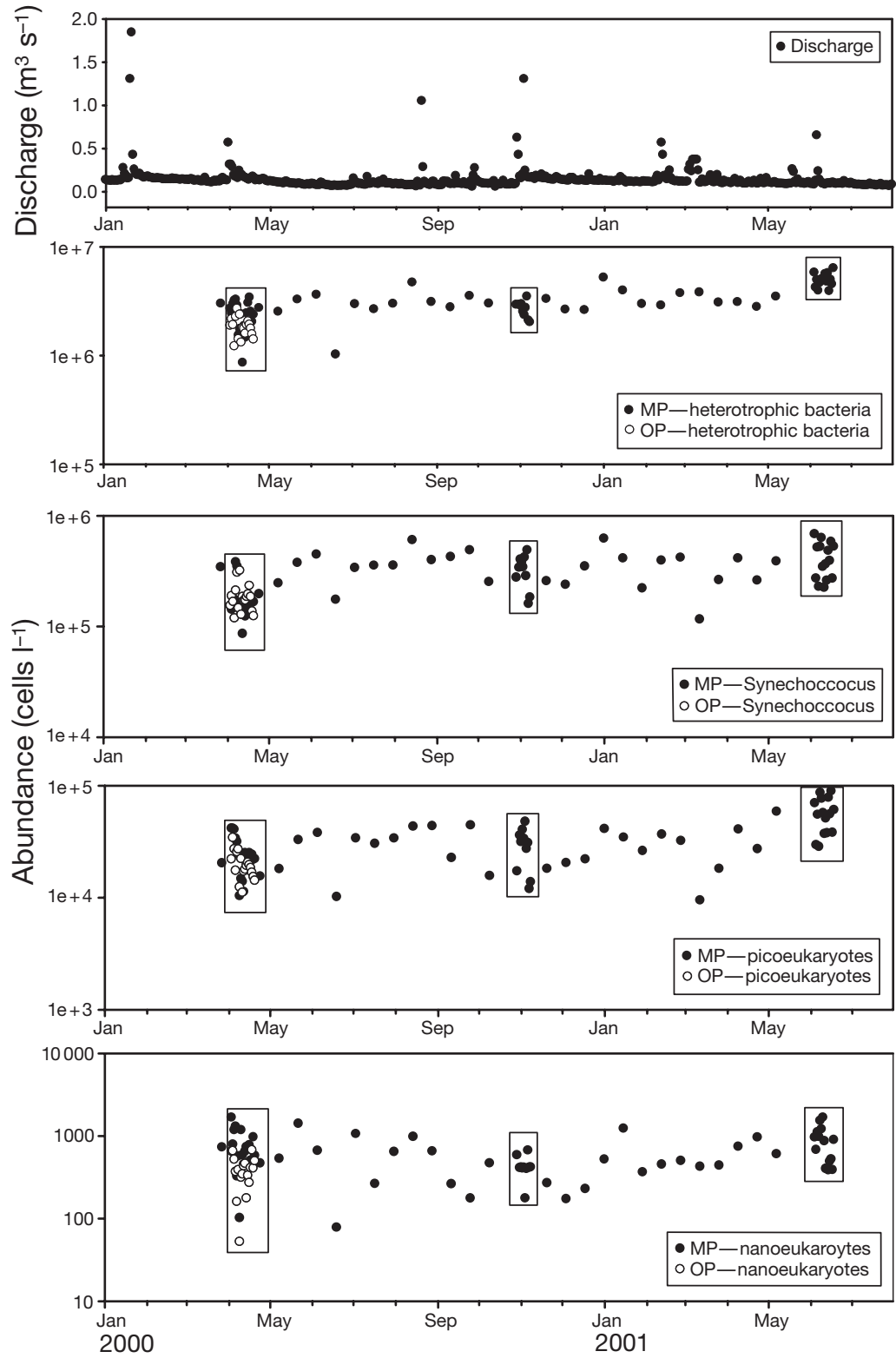

Fig. 10. Microbial fractions at mid plume (MP; 0$)$ and outside plume $(\mathrm{OP} ; \mathrm{O})$ site during pulse-sampling period (NB: baseline data at MP were not collected until April 2000, and August 2000 pulse was not sampled)

we measured (mean of $2.54 \times 10^{5} \mathrm{cells} \mathrm{ml}^{-1}$ ) are within the range reported for surface oligotrophic waters (Campbell \& Vaulot 1993, Campbell et al. 1997, Partensky et al. 1999 a,b, Berninger \& Wickham 2005).

Spectral quality is another factor that could determine the differential distribution between Synechococcus and Prochlorococcus. Prochlorococcus is particularly efficient at absorbing blue wavelengths of light that dominate oceanic oligotrophic waters. Although Synechococcus does not absorb blue light as well as Prochlorococcus, it is capable of absorbing green wavelengths $(500$ to $550 \mathrm{~nm}$ ) that predominate in coastal waters (Ting et al. 2002). Current research (E. Hochberg unpubl.) on spectral quality in Kāne'ohe Bay shows that within the Bay there is more attenuation in blue wavelengths (by phytoplankton as well as dissolved organic matter). Secchi depth and attenuation coefficients (Table 2) also demonstrate differences in the light regimes of the oceanic and Bay sites. Therefore, light availability and - in particular-wavelength composition could be factors contributing to the switch from Prochlorococcus to Synechococcus dominance from oceanic to Bay sites.

The fact that Kāne'ohe Bay waters were devoid of Prochlorococcus was previously pointed out in a short-term study by Liu et al. (1995). In our study, Prochlorococcus was only found at the NB site, even though it dominated the oceanic site. The presence of Prochlorococcus at the NB site may reflect advection into the Bay from oceanic waters, even if populations of Prochlorococcus were unable to grow under the environmental conditions found in the northern sector of the Bay. A similar phenomenon has been described for the advection of Prochlorococcus into Uchin-

coccus grows faster in higher nitrate concentrations (Partensky 1999a,b and references therein). Therefore, Prochlorococcus is expected to be the dominant cell type in oligotrophic conditions when nitrate $<0.1 \mu \mathrm{M}$ (Shalapyonok et al. 2001). Transitions to less oligotrophic conditions are typically associated with a decrease in Prochlorococcus abundance and an increase of Synechococcus and other phytoplankton groups. The oceanic site in our study appears to be permanently oligotrophic (mean nitrate concentration $\sim 0.05 \mu \mathrm{M})$; hence, a dominance of Prochlorococcus would be expected. The Prochlorococcus abundances umi Bay and subsequent failure of population growth (Katano et al. 2005).

Synechococcus at the oceanic site in our study showed higher cell concentrations $\left(7.8 \times 10^{3} \mathrm{cells} \mathrm{ml}^{-1}\right)$ than mean surface values $\left(1.4 \times 10^{3}\right.$ cells ml$\left.^{-1}\right)$ reported for oligotrophic Station ALOHA, $100 \mathrm{~km}$ north of $\mathrm{O}^{\prime} \mathrm{ahu}$, suggesting the export of these cells from Kāne'ohe Bay. Within the Bay, Synechococcus showed a north to south increase in concentration reaching a maximum at the MP site. A positive relationship between cell abundance and nitrate concentrations has been reported for Synechococcus (Agawin et al. 2000, 


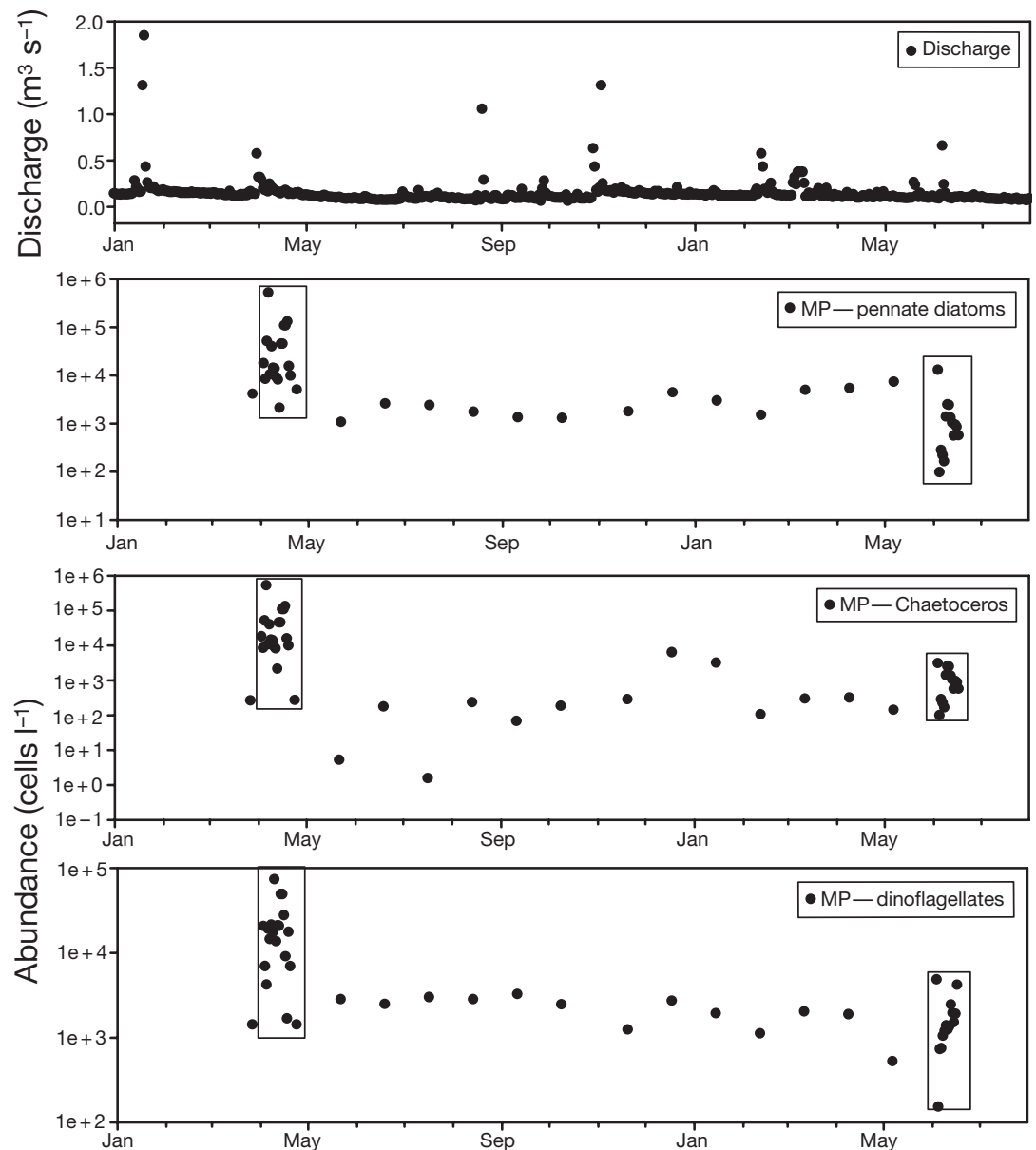

communities to local conditions (in particular, light conditions), as well as retaining plankton cells. Longest water residence time, approximately $13 \mathrm{~d}$, is found at the SB and MP sites (Sunn, Low, Tom, \& Hara Inc. 1976, Smith et al. 1981), where plankton biomass was highest.

Other biotic factors can also affect plankton biomass and community structure. In coral reef systems many macroinvertebrates feed on picoplankton (Pile 1997, Ribes et al. 2003, 2005). The number and distribution of benthic picoplankton consumers such as sponges and ascidians determine the ability of reef systems to capture plankton in this size range (Ribes et al. 2005). Picoplankton consumers in the water column (i.e. appendicularians, Scheinberg 2004, Scheinberg et al. 2005) could also remove significant prokaryotic biomass from the water column. Zooplankton biomass $(>63 \mu \mathrm{m})$ in our study mirrored the spatial distribution pattern of microbial communities, as would be expected for consumers of smaller plankton.

\section{Temporal differences - annual}

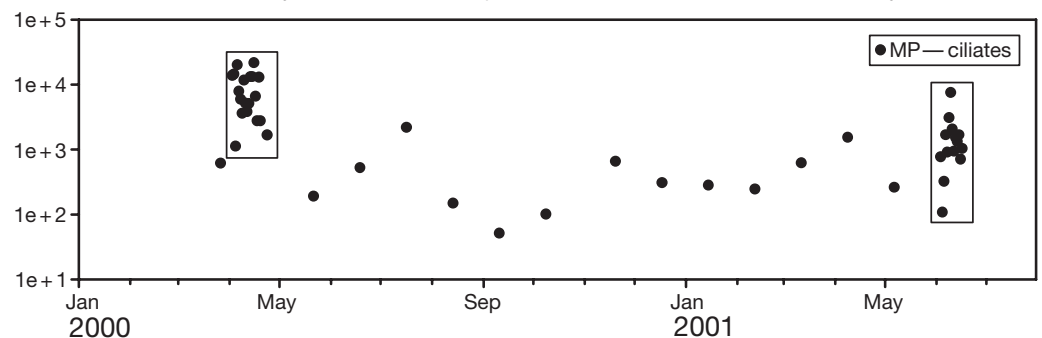

Bi-weekly data did not show clear annual cycles of nutrient concentration and microbial or zooplankton community abundances in Kāne'ohe Bay, as were reported in previous studies (Smith et al. 1981, Taguchi \& Laws 1987, 1989). This could be due to the drought during our sampling period, but also demonstrates that response times of the parameters we measured were shorter than the 2 wk sampling interval of this study. This prompted

Shalapyonok et al. 2001). However, in Kāne'ohe Bay, nitrate concentration does not seem to explain the distribution and abundance of Synechococcus. Glibert et al. (2004) have shown that Synechococcus is capable of utilizing organic sources of nitrogen, and the increase in dissolved organic nitrogen in the order $\mathrm{NB}<\mathrm{CB}<$ $\mathrm{SB}<\mathrm{MP}$ suggests that organic sources of nitrogen may play a role in Synechococcus abundance in the Bay.

Overall, our data indicate that plankton biomass and composition at the study sites within Kāne'ohe Bay could also be influenced by water circulation patterns and residence time. Longer water residence time in more enclosed areas may permit acclimatization of microbial the shorter time scale measurements we recorded during pulses in Kāne'ohe Bay.

When sampling dates were grouped into wet and dry seasons, phosphate and TDP were higher at all sites during the wet season. Nitrate was higher during the wet seasons at the NB and MP sites, as would be expected with discharge from adjacent streams. In contrast, Taguchi \& Laws (1987) found a significant seasonal pattern in nitrate, but not in phosphate, in the southern sector of Kāne'ohe Bay. We found that heterotrophic and photosynthetic microbial concentrations were generally higher during the dry season, suggesting that factors other than elevated dissolved nutrients may determine 
the abundance of most of microbial groups. An exception was Chaetoceros, which showed higher abundances at NB and MP (directly affected by streams) during the wet season. Chaetoceros is an opportunistic species that shows high growth rates in response to increased nutrients (Margalef 1958, Brand \& Guillard 1981). In our study, zooplankton also showed higher concentrations during the dry season. This fact could be explained by the higher concentration of plankton classes on which zooplankton would be feeding.

\section{Temporal differences-daily, during pulses}

Sampling daily during the discharge pulses showed a large increase in nitrate immediately following the rain event. The increases in nitrate concentration varied widely and were not entirely related to the magnitude of the stream discharge, as 4 of the 5 pulses tracked during this study showed a similar peak discharge but produced different increases in nitrate. There was also no consistent relationship between the increase in nitrate and increase in phosphate. Previous history of rain and stream discharge must affect the input of nutrients independently during each pulse. The response of the microbial plankton community was also different among pulses and among plankton groups. Heterotrophic bacteria, Synechococcus, and picoeukaryotes did not show strong responses in cell concentration during the pulses, except following the dry season pulse; however, there was an increase in fluorescence of Synechococcus hours after the pulse was reported. Ringuet \& MacKenzie (2005) also found no change in picoplankton chlorophyll during a bloom in February 2003 in southern Kāne'ohe Bay. Örnólfsdóttir et al. (2004 a,b) found a shift in dominance in biomass from cyanobacteria to diatoms following rivene discharge in Galveston Bay (Texas), and reported that the response was greatest when ambient nitrogen concentrations were lowest. Katano et al. (2005) found that Synechococcus did not respond to experimental addition of nutrients, and showed lower cell concentrations following intrusions of nutrient rich bottom waters into Uchiumi Bay. During our study, large diatoms and dinoflagellates showed a lagged increase in abundance; however, mean silicate concentration at the MP site $(17 \mu \mathrm{M})$ was never limiting for diatom growth (Dortch \& Whitledge 1992). Ringuet \& MacKenzie (2005) also found an increase in diatoms and dinoflagellates following the February 2003 discharge pulse. The increase in abundance in our study was especially evident in the opportunistic genus Chaetoceros. Chaetoceros showed not only a short term response to nutrient enhancement during daily pulse sampling but also seasonal and spatial differences in abundance, associated with nitrate concentrations.
Clearly, responses of picoplankton and other phytoplankton are also influenced by the population dynamics of small grazers. Scheinberg (2005) described increases in copepods, appendicularians, cladocerans, larval bivalves and polychaetes following a storm event in Kāne'ohe Bay in November 2003. The zooplankton community shifted from small copepods to large, gelatinous zooplankton and larval meroplankton, demonstrating that not only bottom-up (increases in nutrients) but also top-down (grazing by zooplankton) factors influence the composition and abundance of plankton. Berninger \& Wickham (2005) found that grazing control was stronger for the smaller pico- and nano-plankton groups, whereas microplankton were nutrient limited.

Our data provide new insights into the type and timing of responses of different planktonic groups to environmental changes. Picophytoplankton responded to pulsed discharge with an increase in fluorescence per cell in a time scale of hours, apparently related to reduced light availability following increased TSS during pulse events. Increases in nutrients during pulse events favored microphytoplankton growth with a time response of several days. These shifts may only be evident when pulses are large in magnitude, or water residence time is longer than the lag in response of phytoplankton. Shifts of phytoplankton to larger sizes following nutrient enrichments have been documented in marine waters (Chisholm 1992, Webber et al. 1992, Nakamura et al. 1993, Chang et al. 1996, Agawin et al. 2000, 2003, Örnólfsdóttir et al. 2004 a,b); however, this work provides new insights into the immediate shift in fluorescence, changes in abundance and species composition within the microbial community, and the temporal and spatial extent of these changes. Differences in plankton community composition and species abundance between oceanic and Bay waters seem to be primarily related to physical factors (water circulation patterns and light availability). It seems evident that plankton populations in Kāne'ohe Bay are autochthonous and do not rely upon an external (oceanic) source of nutrients, whereas oceanic sites (at least those within a few kilometres of Kāne'ohe Bay) may receive some nutrients or plankton from the inshore waters.

Acknowledgements. This paper was partially funded by NOAA: CISNet (NOAA project NA 870A0531) and University of Hawai'i Sea Grant Project NA36RG0507. Thanks to Paul Jokiel and the people of Point Lab (HIMB) for a pleasant working environment, valuable discussions, and assistance. We thank numerous students who helped with all sample collection and processing. We thank Eric Hochberg who shared unpublished data. The manuscript was improved by comments from 3 anonymous reviewers. Support for this work was provided by a Postdoctoral Fellowship from the 'Ministerio de Educación y Cultura, MEC' and a RyC research contract to M.R. Additional funding was provided to M.R. by TRANSCOM project (REN2002-01631/MAR). This is HIMB contribution 1225 . 


\section{LITERATURE CITED}

Agawin NSF, Duarte CM, Agusti S (2000) Nutrient and temperature control of the contribution of picoplankton to phytoplankton biomass and production. Limnol Oceanogr 45:591-600

Agawin MSR, Duarte CM, Agusti S, McManus L (2003) Abundance, biomass and growth rates of Synechococcus sp. in a tropical coastal ecosystem (Philippines, South China Sea). Estuar Coastal Shelf Sci 56:493-502

Atkinson MJ, Smith SV (1983) C.N.P rations of benthic marine plants. Limnol Oceanogr 28:568-574

Banner AH (1974) Kaneohe Bay, Hawaii: urban pollution and a coral reef ecosystem. Proc 2nd Int Coral Reef Symp 2: 685-702

Bathen KH (1968) A descriptive study of the physical oceanography of Kaneohe Bay, Oahu, Hawaii. Hawaii Institute of Marine Biology Technical Report 14, Kane'ohe, HI

Berninger UG, Wickham SA (2005) Response of the microbial food web to manipulation of nutrients and grazers in the oligotrophic Gulf of Aqaba and northern Red Sea. Mar Biol 147:1033-1044

Brand LE, Guillard RRL (1981). The effects of continuous light and irradiance on the reproduction rates of twenty-two species of marine phytoplankton. J Exp Mar Biol Ecol 50: $119-132$

Campbell L, Vaulot D (1993) Photosynthetic picoplankton community structure in the subtropical North Pacific Ocean near Hawaii (station ALOHA). Deep-Sea Res I 40: 2043-2060

Campbell L, Liu H, Nolla HA, Vaulot D (1997) Annual variability of phytoplankton and bacteria in the subtropical North Pacific Ocean at Station ALOHA during the 19911994 ENSO event. Deep-Sea Res I 44:167-192

Capone DG (1983) Benthic nitrogen fixation. In: Carpenter EJ, Capone DG (eds) Nitrogen in the marine environment. Academic Press, New York, p 105-137

Caron DA, Dam GF, Kremer P, Lessard EJ and 6 others (1995) The contribution of microorganisms to particulate carbon and nitrogen in surface waters of the Sargasso Sea near Bermuda. Deep-Sea Res I 42:943-972

Chang J, Chung C, Gong G (1996) Influences of cyclones on chlorophyll a concentration and Synechococcus abundance in a subtropical western Pacific coastal ecosystem. Mar Ecol Prog Ser 140:199-205

Charpy L (1996) Phytoplankton biomass and production in two Tuamotu atoll lagoons (French Polynesia). Mar Ecol Prog Ser 145:133-142

Charpy L, Blanchot J (1998) Photosynthetic picoplankton in French Polynesian atoll lagoons: estimation of taxa contribution to biomass and production by flow cytometry. Mar Ecol Prog Ser 162:57-70

Charpy-Roubaud CJ, Charpy L, Cremoux JL (1990) Nutrient budget of the lagoonal waters in an open central South Pacific atoll (Tikehau, Tuamotu, French Polynesia). Mar Biol 107:67-73

Chisholm SW (1992) Phytoplankton size. In: Falkowski PC Woodhead AD (eds) Primary productivity and biogeochemical cycles in the sea. Plenum Press, New York, p 213-237

Crossland CJ, Barnes DJ (1983) Dissolved nutrients and organic particulates in water flowing over coral reefs at Lizard Island. Aust J Mar Freshw Res 34:835-844

D'Elia CF, Wiebe WJ (1990) Biogeochemical nutrient cycles in coral reef ecosystems. In: Dubinsky Z (ed) Ecosystems of the world 25: coral reefs. Elsevier, New York
Dortch Q, Whitledge TE (1992) Does nitrogen or silicon limit phytoplankton production in the Mississippi River plume and nearby regions? Cont Shelf Res 12:1293-1309

Dubinsky Z, Stambler N (1996) Eutrophication, marine pollution and coral reefs. Global Change Biol 2:511-526

Ducklow HW (1990) Biomass, production and fate of bacteria. In: Dubinsky Z (ed) Ecosystems of the world 25: coral reefs. Elsevier, New York

Edler L (1979) Recommendations for marine biological studies in the Baltic sea. Phytoplankton and chlorophyll. Baltic Mar Biol 5:5-38

Ferrier-Pagès C, Furla P (2001) Pico- and nanoplankton biomass and production in the two largest atoll lagoons of French Polynesia. Mar Ecol Prog Ser 211:63-76

Furnas MJ (1992) The behavior of nutrients in tropical aquatic ecosystems. In: Connell DW, Hawker DW (eds) Land use patterns and nutrient loadings of the Great Barrier Reef Region. James Cook University, Townsville

Furnas MJ, Mitchell A, Skuza M, Brodie J (2005) In the other $90 \%$ : phytoplankton response to enhanced nutrient availability in the Great Barrier Reef Lagoon. Mar Pollut Bull 51:253-265.

Gasol JM, Morán XAG (1999) Effects of filtration on bacterial activity and picoplankton community structure as assessed by flow cytometry. Aquat Microb Ecol 16:251-264

Gasol JM, del Giorgio P (2000) Using flow cytometry for counting natural planktonic bacteria and understanding the structure of planktonic bacterial communities. Sci Mar 64:197-224

Glibert PM, Heil CA, Hollander D, Revilla M, Hoare A, Alexander J, Murasko S (2004) Evidence for dissolved organic nitrogen and phosphorus uptake during a cyanobacterial bloom in Florida Bay. Mar Ecol Prog Ser 280:73-83

Gundersen K, Heldal M, Norland S, Purdie DA, Knap AH (2002) Elemental C, N, and P cell content of individual bacteria collected at the Bermuda Atlantic Time-series Study (BATS) site. Limnol Oceanogr 47:1525-1530

Hatcher BG (1990) Coral reef primary productivity: a hierarchy of pattern and process. Trends Ecol Evol 5(5):149-155

Heldal M, Scanlan DJ, Norland S, Thingstad F, Mann NH (2003) Elemental composition of single cells of various strains of marine Prochlorococcus and Synechococcus using X-ray microanalysis. Limnol Oceanogr 48:1732- 1743

Hoover DJ (2002) Fluvial nitrogen and phosphorus in Hawaii: storm runoff, land use, and impacts on coastal waters. $\mathrm{PhD}$ dissertation, University of Hawaii, Honolulu

Hunter CL, Evans CW (1995) Coral reefs in Kaneohe Bay, Hawaii: two centuries of western influence and two decades of data. Bull Mar Sci 57:501-515

Jokiel PL, Hunter CL, Taguchi S, Watarai L (1993) Ecological impact of a fresh water 'reef kill' on the reefs of Kaneohe Bay, Oahu, Hawaii. Coral Reefs 12:177-184

Kana T, Glibert PM (1987) Effect of irradiances up to $2000 \mathrm{mE}$ $\mathrm{m}^{-2} \mathrm{~s}^{-1}$ on marine Synechococcus WH 7803-1. Growth, pigmentation, and cell composition. Deep-Sea Res 34: 479-516

Katano T, Kaneda A, Takeoka H, Nakano S (2005) Seasonal changes in the abundance and composition of picophytoplankton in relation to the occurrence of 'Kyucho' and bottom intrusion in Uchiumi Bay, Japan. Mar Ecol Prog Ser 298:59-67

Kinzie III RA, Chong C, Devrell J, Linstrom D, Wolff R (2006) Effects of water removal on a Hawaiian stream ecosystem. Pac Sci 60:1-47

Laws EA, Allen CB (1996) Water quality in a subtropical embayment more than a decade after diversion of sewage discharges. Pac Sci 50:194-210 
Laws EA, Roth L (2004) Impact of stream hardening on water quality and metabolic characteristics of Waimnalo and Kāne`ohe Streams, O'ahu, Hawaiian Islands. Pac Sci 58: 261-280

Liu HB, Campbell L, Landry MR (1995) Growth and mortality rates of Prochlorococcus and Synechococcus measured with a selective inhibitor technique. Mar Ecol Prog Ser 116:277-287

Margalef R (1958) Temporal succession and spatial heterogeneity in natural phytoplankton. In: Buzzati-Traverso AA (ed) Perspectives in marine biology. University of California Press, Los Angeles, p 323-349

Massana R, Gasol JM, Bjarnsen PK, Blackburn N and 5 others (1997) Measurement of bacterial size via image analysis of epifluorescence preparations: description of an inexpensive system and solutions to some of the most common problems. Sci Mar 61:397-407

Montagnes DJ, Berges SJA, Harrison PJ, Taylor FJR (1994) Estimating carbon, nitrogen, protein and chlorophyll a from volume in marine phytoplankton. Limnol Oceanogr 39:1044-1060

Moore LR, Goericke R, Chisholm SW (1995) Comparative physiology of Synechococcus and Prochlorococcus: influence of light and temperature on growth pigments fluorescence and absorptive properties. Mar Ecol Prog Ser 116:259-275

Moore LR, Post AF, Rocap G, Chisholm SW (2002) Utilization of different nitrogen sources by the marine cyanobacteria Prochlorococcus and Synechococcus. Limnol Oceanogr 47:989-996

Nakamura Y, Sasaki S, Hiromi J, Fukami K (1993) Dynamics of picocyanobacteria in the Seto Inland Sea (Japan) during the summer. Mar Ecol Prog Ser 96:117-124

Oki DS (2004) Trends in streamflow characteristics at longterm gaging stations, Hawaii. US Geol Surv Sci Invest Rep 2004-5080. US Geological Survey, Honolulu, HI

Olson RJ, Chisholm SW, Zettler ER, Armbrust EV (1990a) Pigments, size, and distribution of Synechococcus in the North Atlantic and Pacific Oceans. Limnol Oceanogr 35: $45-58$

Olson RJ, Chisholm SW, Zettler ER, Altabet MA, Dusenberry JA (1990b) Spatial and temporal distributions of prochlorophyte picoplankton in the North Atlantic Ocean. Deep-Sea Res 37:1033-1051

Örnólfsdóttir EB, Lumsden SE, Pinckney JL (2004a) Phytoplankton community growth-rate response to nutrient pulses in a shallow turbid estuary, Galveston Bay, Texas. J Plankton Res 26:325-339

Örnólfsdóttir EB, Lumsden SE, Pinckney JL (2004b) Nutrient pulsing as a regulator of phytoplankton abundance and community composition in Galveston Bay, Texas. J Exp Mar Biol 303:197-220

Partensky F, Blanchot J, Vaulot D (1999a) Differential distribution and ecology of Prochlorococcus and Synechococcus in oceanic waters: a review. Bull Inst Oceangr Monaco 19: 431-449

Partensky F, Hess WR, Vaulot D (1999b) Prochlorococcus, a marine photosynthetic prokaryote of global significance. Microb Mol Biol Rev 63:106-127

Pile AJ (1997) Finding Reswig's missing carbon: quantification of sponge feeding using dual beam flow cytometry. Proc 8th Int Coral Reef Symp 2:1403-1410

Rasheed M, Badran MI, Richter C, Huettel M (2002) Effect of reef framework and bottom sediment on nutrient enrichment in a coral reef of the Gulf of Aqaba, Red Sea. Mar Ecol Prog Ser 239:277-285
Raven JA (1998) Small is beautiful: the picophytoplankton. Funct Ecol 12:503-513

Ribes M, Coma R, Atkinson MJ, Kinzie RA III (2003) Particle removal by coral reef communities: picoplankton is a major source of nitrogen. Mar Ecol Prog Ser 257:13-23

Ribes M, Coma R, Atkinson MJ, Kinzie RA III (2005) The role of sponges and ascidians in removal of picoplankton from coral reef water. Limnol Oceanogr 50:1480-1489

Ringuet S, MacKenzie FT (2005) Controls on nutrient and phytoplankton dynamics during normal flow and storm runoff conditions, Southern Kaneohe Bay, Hawaii. Estuaries 28:327-337

Scharek R, Latasa M, Karl DV, Bidigare RR (1999) Temporal variation in diatom abundance and downward vertical flux in the oligotrophic North Pacific gyre. Deep-Sea Res I 46:1051-1075

Scheinberg RD (2004) Food web structure and trophic dynamics of a subtropical plankton community, with an emphasis on appendicularians. PhD dissertation, University of Hawaii, Honolulu

Scheinberg RD, Landry MR, Calbet A (2005) Grazing of two common appendicularians on the natural prey assemblage of a tropical coastal ecosystem. Mar Ecol Prog Ser 294:201-212

Shalapyonok A, Olson RJ, Shalapyonok LS (2001) Arabian Sea phytoplankton during Southwest and Northeast Monsoons 1995: composition, size structure and biomass from individual cell properties measured by flow cytometry. Deep-Sea Res II 48:1231-1261

Smith SV, Kimmerer WJ, Laws EA, Brock RE, Walsh TW (1981) Kaneohe Bay sewage diversion experiment: perspectives on ecosystem response to nutritional perturbation. Pac Sci 35:279-395

Sunn, Low, Tom, \& Hara Inc. (1976) Kaneohe Bay Urban Water Resources Study. US Army Corps of Engineers, Honolulu

Tada K, Sakai K, Nakano Y, Takemura A, Montani S (2003) Size-fractionated phytoplankton biomass in coral reef waters off Sesoko Island, Okinawa, Japan. J Plankton Res 25:991-997

Taguchi S, Laws EA (1987) Patterns and causes of temporal variability in the physiological condition of the phytoplankton community in Kaneohe Bay, Hawaii. J Plankton Res 9:1143-1157

Taguchi S, Laws EA (1989) Biomass and compositional characteristics of Kaneohe Bay, Oahu, Hawaii, phytoplankton inferred from regression analysis. Pac Sci 43:316-331

Ting CS, Rocap G, King J, Chisholm SW (2002) Cyanobacterial photosynthesis in the oceans: the origins and significance of divergent light-harvesting strategies. Trends Microbiol 10:134-142

Tremblay JE, Legendre L (1994) A model for the size-fractioned biomass and production of marine phytoplankton. Limnol Oceanogr 39:2004-2014

Trees CC, Bidigare RR, Karl DM, Van Heukelem L (2000) Fluorometric chlorophyll a: sampling, laboratory methods and data analysis protocols. In: Fargion GS, Mueller JS (eds) Ocean optics protocols for satellite ocean color sensor validation, revision 2. NASA, Greenbelt, MD

Webber DF, Webber MK, Roff JC (1992) Effects of flood waters on the planktonic community of the Hellshire Coast, southeast Jamaica. Biotropica 24:362-374

Williams SL, Carpenter RC (1998) Effects of unidirectional and oscillatory water flow on nitrogen fixation (acetylene reduction) in coral reef algal turfs, Kaneohe Bay, Hawaii. J Exp Mar Biol Ecol 226:293-316

Submitted: November 19, 2005; Accepted: March 16, 2006

Proofs received from author(s): September 21, 2006 